\title{
Landscape of Tumor Suppressor Mutations in Acute Myeloid Leukemia
}

\author{
Cristina Panuzzo ${ }^{1, \dagger}$, Elisabetta Signorino ${ }^{1,+}$, Chiara Calabrese ${ }^{1}$, Muhammad Shahzad Ali ${ }^{1}$, \\ Jessica Petiti ${ }^{1}\left[\right.$, Enrico Bracco ${ }^{2, \mp(1)}$ and Daniela Cilloni ${ }^{1, *, \ddagger(1)}$ \\ 1 Department of Clinical and Biological Sciences, University of Turin, 10124 Turin, Italy; \\ cristina.panuzzo@unito.it (C.P.); elisabetta.signorino@unito.it (E.S.); k.kalabrese81@gmail.com (C.C.); \\ shahzad.sbs@pu.edu.pk (M.S.A.); jessica.petiti@unito.it (J.P.) \\ 2 Department of Oncology, University of Turin, 10124 Turin, Italy; enrico.bracco@unito.it \\ * Correspondence: daniela.cilloni@unito.it; Tel.: +39-011-9026610; Fax: +39-011-9038636 \\ + These authors share the co-first authorship. \\ $\ddagger$ These authors share the co-last authorship.
}

Received: 2 February 2020; Accepted: 12 March 2020; Published: 16 March 2020

\begin{abstract}
Acute myeloid leukemia is mainly characterized by a complex and dynamic genomic instability. Next-generation sequencing has significantly improved the ability of diagnostic research to molecularly characterize and stratify patients. This detailed outcome allowed the discovery of new therapeutic targets and predictive biomarkers, which led to develop novel compounds (e.g., IDH 1 and 2 inhibitors), nowadays commonly used for the treatment of adult relapsed or refractory AML. In this review we summarize the most relevant mutations affecting tumor suppressor genes that contribute to the onset and progression of AML pathology. Epigenetic modifications (TET2, IDH1 and IDH2, DNMT3A, ASXL1, WT1, EZH2), DNA repair dysregulation (TP53, NPM1), cell cycle inhibition and deficiency in differentiation (NPM1, CEBPA, TP53 and GATA2) as a consequence of somatic mutations come out as key elements in acute myeloid leukemia and may contribute to relapse and resistance to therapies. Moreover, spliceosomal machinery mutations identified in the last years, even if in a small cohort of acute myeloid leukemia patients, suggested a new opportunity to exploit therapeutically. Targeting these cellular markers will be the main challenge in the near future in an attempt to eradicate leukemia stem cells.
\end{abstract}

Keywords: acute myeloid leukemia; tumor suppressors; mutations; overall survival; relapse; epigenetic; DNA repair; cell cycle

\section{Introduction}

Acute myeloid leukemia (AML) is the most common acute blood malignancy in adults [1], and it arises as the result of somatically acquired genetic alterations in hematopoietic stem cells (HSCs) [2-4]. The incidence of AML increases with age. Though in recent years improvements in therapies led to more favorable prognosis for younger patients, in the elderly the outcome still remains adverse [5]. In most cases AML appears as a de novo disease, but it can also occurs in patients with a previously diagnosed hematological disorder, such as myelodysplastic syndromes (MDSs) or Philadelphia-negative myeloproliferative neoplasms ( $\mathrm{Ph}^{-} \mathrm{MPNs}$ [6], and in these cases it is usually more resistant to conventional chemotherapy treatments [7]. The pathogenesis of AML shows an excessive proliferation, reduced differentiation and decreased apoptosis of stem cells of myeloid lineage $[6,8]$. Normal precursors in the bone marrow are replaced with excessively proliferating malignant leukemic cells, leading to hematopoietic failure [8,9]. Leukocytosis and bone marrow failure are common AML clinical signs, whereas infection or bleeding are common cause of death when 
AML is left untreated $[1,10]$. There are four frequent translocations in AML, namely PML-RAR $\alpha$, AML1(RUNX1)-ETO(RUNX1T1), CBF $\alpha$-MYH11 and MLL-fusions, and also other low-incidence oncofusion genes [7]. Furthermore, in the majority of cases, genetic mutations appear without any cytogenetic aberration [11,12]. AML patients are divided into three groups, based on their cytogenetical status: favorable, intermediate and adverse risk (Table 1) [10]. AML was among the first cancers to be studied by innovative microarray and sequencing techniques [13], concluding that AML is a complex disease evolving through time $[11,14,15]$. In The Cancer Genome Atlas (TCGA) project for AML, several genes such as FLT3, NPM1, DNMT3A, CEBPA, IDH1 and IDH2, were found to be recurrently mutated, as well as others never documented before in the pathogenesis of leukemia, including EZH2 [12]. Some common mutations in AML were found to be directly implicated in the pathogenesis of the disease, being mutually exclusive with all fusion oncogenes involving transcription factors. Moreover, the TCGA project also revealed that in AML the clonal population is indeed heterogeneous, and several subclones may coexist [12]; those clones often bear mutations in genes involved in epigenetic regulation. These observations suggest that they arise as early events, persist over time, survive leukemia chemotherapy and eventually cause relapse [14-17]. Currently, in routine clinical practice, diagnosis of AML is confirmed with blast count $\geq 20 \%$ on bone marrow smear, immunophenotyping and cytogenetical analysis recognizing chromosomal rearrangements (karyotyping and FISH analysis) combined with molecular analysis of mutated genes, such as NPM1, CEBPA, RUNX1, FLT3 (both internal tandem duplication (ITD) and tyrosine kinase domain (TDK)), ASXL1 and TP53 [10]. Other mutations should be evaluated in case of available clinical trials with new drugs, such specific inhibitors for IDH1 and IDH2, or hypomethylating agents in the presence of WT1 and TET2 mutations. In this review, we will outline a picture of the most frequently mutated tumor suppressor genes in AML, such as IDH1, IDH2, TET2, DNMT3A and WT1 (Table 2), NPM1, CEBPA and TP53 (Table 3) (Tables 2 and 3), as well as others recently discovered to be involved in the disease with a lower mutation frequency, including EZH2, GATA2, splicing factors and miRNAs (Figure 1).

Table 1. Cytogenetic and molecular profile of prognostic-risk groups.

\begin{tabular}{|c|c|}
\hline Prognostic-Risk Group & Cytogenetic Aberrations and Molecular Abnormalities \\
\hline Favorable & $\begin{array}{c}\mathrm{t}(8: 21)(\mathrm{q} 22 ; \mathrm{q} 22) A M L 1(R U N X 1)-E T O(R U N X 1 T 1) \\
\operatorname{inv}(16)(\mathrm{p} 13 ; 1 \mathrm{q} 22) C B F \alpha-M Y H 11 \\
\mathrm{t}(15 ; 17)(\mathrm{q} 22 ; \mathrm{q} 12) P M L-R A R \alpha \\
\text { CEBPA biallelic mutations }\end{array}$ \\
\hline Intermediate & 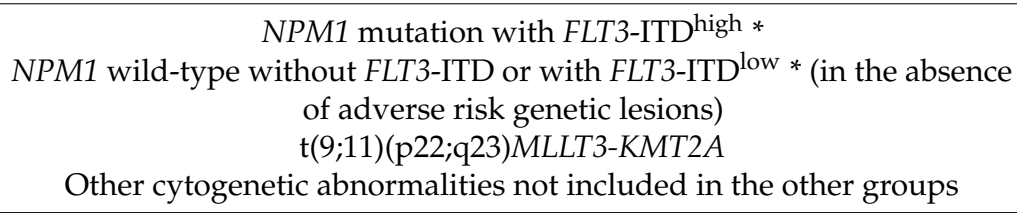 \\
\hline Adverse & $\begin{array}{c}\mathrm{t}(6 ; 9)(\mathrm{p} 23 ; \mathrm{q} 34) D E K / N U P 214 \\
\operatorname{inv}(3)(\mathrm{q} 21 ; \mathrm{q} 26.2) G A T A 2, M E C O M(E V I 1) \\
\mathrm{t}(9 ; 22)(\mathrm{q} 34.1 ; \mathrm{q} 11.2) B C R-A B L 1 \\
\mathrm{t}(\mathrm{v} ; 11 \mathrm{q} 23.3) K M T 2 A(M L L) \text { rearranged } \\
-5 \text { or del }(5 \mathrm{q}) \\
-7 \text { or del }(7 \mathrm{q}) \\
\text { abn }(17 \mathrm{p}) \\
\text { Complex karyotype } \\
\text { Monosomal karyotype } \\
\text { NPM1 wild-type and FLT3-ITD high * } \\
\text { RUNX1 mutations (in the absence of favorable risk genetic lesions) } \\
\text { ASXL1 mutations (in the absence of favorable risk genetic lesions) } \\
\text { TP53 mutations }\end{array}$ \\
\hline
\end{tabular}

\footnotetext{
${ }^{*}$ Low, low allelic ratio $(<0.5) ;{ }^{*}$ high, high allelic ratio $(\geq 0.5)$.
} 
Table 2. Summary and features of AML mutated tumor suppressors involved in epigenetic mechanisms.

\begin{tabular}{|c|c|c|}
\hline \multicolumn{3}{|c|}{ Mutated Tumor Suppressors Involved in Epigenetic Regulation } \\
\hline Mutated Genes & $\begin{array}{l}\text { Frequency in } \\
\text { AML (\%) }\end{array}$ & Functions, Associations, Prognostic Impact and Specific Drugs \\
\hline IDH1 & $6-10$ & $\begin{array}{c}\text { Enzyme involved in TCA cycle } \\
\text { Important role in lipid metabolism } \\
\text { Involved in cellular defense of oxidative damage } \\
\text { Mutations cause D-2-hydroxyglutarate (D2HG) accumulation that } \\
\text { inhibits various dioxygenases involved in epigenetic regulation } \\
\text { Frequent in CN-AML } \\
\text { Associated with NPM1 mutations } \\
\text { Associated with FLT3, DNMT3A, ASXL1, RUNX1, NRAS mutations } \\
\text { Mutually exclusive with TET2 mutations } \\
\text { Associated with clonal hematopoiesis in healthy elderly persons } \\
\text { Early event in leukemogenesis } \\
\text { Prognostic impact context-dependent } \\
\text { IDH1 inhibitor ivosidenib approved by FDA }\end{array}$ \\
\hline $\operatorname{IDH} 2^{\mathrm{R} 140}$ & $5-15$ & $\begin{array}{c}\text { Enzyme involved in TCA cycle } \\
\text { Involved in cellular defense of oxidative damage } \\
\text { Mutations cause D-2-hydroxyglutarate (D2HG) accumulation that } \\
\text { inhibits various dioxygenases involved in epigenetic regulation } \\
\text { Frequent in CN-AML } \\
\text { Frequency increases with age } \\
\text { Associated with NPM1 mutations } \\
\text { Associated with FLT3, DNMT3A, ASXL1, RUNX1, NRAS mutations } \\
\text { Mutually exclusive with TET2 mutations } \\
\text { Associated with clonal hematopoiesis in healthy elderly persons } \\
\text { Early event in leukemogenesis } \\
\text { Prognostic impact could be more favorable than other IDH mutations } \\
\text { IDH2 inhibitor enasidenib approved by FDA }\end{array}$ \\
\hline $\operatorname{IDH} 2^{\mathrm{R} 172}$ & $1-4$ & $\begin{array}{c}\text { Enzyme involved in TCA cycle } \\
\text { Involved in cellular defense of oxidative damage } \\
\text { Mutations cause D-2-hydroxyglutarate (D2HG) accumulation that } \\
\text { inhibits various dioxygenases involved in epigenetic regulation } \\
\text { Frequent in CN-AML } \\
\text { AML with IDH } 2^{R 172} \text { mutation (in the absence of other lesions) may } \\
\text { represent a separate disease class, associated with a distinct } \\
\text { microarray gene expression and microRNA expression profile } \\
\text { Mutually exclusive with NPM1 mutations } \\
\text { Associated with FLT3, DNMT3A, ASXL1, RUNX1, NRAS mutations } \\
\text { Mutually exclusive with TET2 mutations } \\
\text { No consistent data on prognostic impact } \\
\text { Associated with clonal hematopoiesis in healthy elderly persons } \\
\text { Early event in leukemogenesis } \\
\text { IDH2 inhibitor enasidenib approved by FDA }\end{array}$ \\
\hline DNMT3A & $15-30$ & $\begin{array}{c}\text { Catalyzes the addition of a methyl group to the cytosine residue of } \\
\text { CpG dinucleotides } \\
\text { Essential for de novo DNA methylation and regulation of gene } \\
\text { expression } \\
\text { Frequent in CN-AML } \\
\text { Frequency increases with age } \\
\text { mutation } \\
\text { Associated with NPM1, FLT3-ITD,IDH1,IDH2 }{ }^{R 140} \text { and IDH2 }{ }^{R 172} \\
\text { Prognostic impact not consistent and context-dependent } \\
\text { Particularly poor prognosis in DNMT3Amut/NPM1mut/FLT3-ITD } \\
\text { Persistent DNMT3A transcript levels in hematologic CR } \\
\text { Associated with clonal hematopoiesis in healthy elderly persons } \\
\text { Early event in leukemogenesis }\end{array}$ \\
\hline
\end{tabular}


Table 2. Cont.

\begin{tabular}{|c|c|c|}
\hline \multicolumn{3}{|c|}{ Mutated Tumor Suppressors Involved in Epigenetic Regulation } \\
\hline Mutated Genes & $\begin{array}{c}\text { Frequency in } \\
\text { AML }(\%)\end{array}$ & Functions, Associations, Prognostic Impact and Specific Drugs \\
\hline TET2 & $12-34$ & $\begin{array}{c}\text { Regulates differentiation or proliferation and epigenetic modifications } \\
\text { Key family of enzymes for DNA demethylation } \\
\text { Frequent in CN-AML } \\
\text { Frequency increases with age } \\
\text { Associated with NPM1 mutation } \\
\text { Mutually exclusive with IDH1 and IDH2 mutations } \\
\text { Prognostic impact associated with inferior OS in CN-AML } \\
\text { Associated with clonal hematopoiesis in healthy elderly persons } \\
\text { Early event in leukemogenesis } \\
\text { Mutations in TET2 may respond to hypomethylating agents (HMAs) } \\
\text { therapy }\end{array}$ \\
\hline WT1 & $6-15$ & $\begin{array}{c}\text { Zinc finger transcription factor } \\
\text { Multiple isoforms from two splicing events } \\
\text { Involved in regulation of cell survival, proliferation, and } \\
\text { differentiation } \\
\text { Overexpressed in AML where it is used as a diagnostic molecular } \\
\text { marker and for MRD monitoring } \\
\text { Overexpression correlate with chemotherapy resistance, decreased OS } \\
\text { and higher relapse rate } \\
\text { Mutations in exons 1, } 7 \text { and } 9 \text { in AML } \\
\text { Frequent in younger patients } \\
\text { Associated with FLT3-ITD and CEBPA biallelic mutation } \\
\text { Associated with worse prognosis and resistance to chemotherapy } \\
\text { Possible role in the same epigenetic pathway of TET2 and IDH1/2 } \\
\text { Anticorrelated with TET2, IDH1 and IDH2 mutations } \\
\text { Use of HMAs such azacitidine as a potential strategy of therapy in } \\
\text { WT1 mutated patients } \\
\text { Polymorphism SNP rs16754 positive prognostic factor in patients with } \\
\text { AML }\end{array}$ \\
\hline ASXL1 & $5-18$ & $\begin{array}{c}\text { Chromatin-binding protein, epigenetic scaffold protein } \\
\text { Enhancer of the trithorax and polycomb genes } \\
\text { Mutations in the ASXL1 described in many subtypes of myeloid } \\
\text { malignances } \\
\text { Associated with adverse prognosis, shorter OS and higher risk of } \\
\text { progression } \\
\text { Frequent in CMML } \\
\text { Frequency increases significantly with age } \\
\text { Correlate with } \mathrm{t}(8 ; 21),+8 \text { and }-7 \text { chromosomal aberrations } \\
\text { Associated with } R \text { RUN1 and IDH2 mutations } \\
\text { Associated with clonal hematopoiesis in healthy elderly persons } \\
\text { Early event in leukemogenesis }\end{array}$ \\
\hline
\end{tabular}


Table 3. Summary and features of AML mutated tumor suppressors involved in non-epigenetic mechanisms.

\begin{tabular}{|c|c|c|}
\hline \multicolumn{3}{|c|}{ Mutated Tumor Suppressors Involved in Non-Epigenetic Mechanisms } \\
\hline Mutated Genes & $\begin{array}{l}\text { Frequency in } \\
\text { AML }(\%)\end{array}$ & Functions, Associations, Prognostic Impact and Specific Drugs \\
\hline NPM1 & $25-30$ & $\begin{array}{c}\text { Nucleus-cytoplasm shuttling protein } \\
\text { Involved in the regulation of centrosome duplication, DNA repair, ribosomal } \\
\text { protein assembly and apoptotic response to oncogenic stimuli } \\
\text { Key regulator of tumor suppressors TP53 and p19ARF } \\
\text { Frequent in adult CN-AML } \\
\text { Mutations mostly located into exon } 12 \\
\text { Correlates with good response to conventional therapy } \\
\text { Classified as favorable risk, high complete remission rates, EFS and OS } \\
\text { Co-occurrence with FLT3 mutation associated with an intermediate prognosis } \\
\text { Associated with DNMT3A, IDH1, IDH2 and TET2 mutations } \\
\text { Used for monitoring of MRD }\end{array}$ \\
\hline $\begin{array}{c}\text { CEBPA } \\
\text { (biallelic) }\end{array}$ & $5-20$ & $\begin{array}{c}\text { Zinc finger transcription factor } \\
\text { Regulates differentiation of multipotent precursor cells to myeloid progenitors } \\
\text { Directs granulocyte and monocyte differentiation } \\
\text { Controls self-renewal properties of hematopoietic stem and progenitor cells } \\
\text { Frequent in de novo AML } \\
\text { Frequently biallelic } \\
\text { Biallelic mutations are associated with favorable prognosis if compared to } \\
\text { single allele mutation } \\
\text { AML subgroup with CEBPA mutations recognized as a distinct diagnostic } \\
\text { entity by the 2016 WHO classification of myeloid neoplasms } \\
\text { Direct transcriptional repression by AML1-ETO, RAR } \alpha \text {-PLZF and FLT-ITD } \\
\text { Associated with TET2, GATA2, WT1, DNMT3A and ASXL1 mutations } \\
\text { Associated with a more favorable prognosis }\end{array}$ \\
\hline TP53 & $5-20$ & $\begin{array}{c}\text { Guardian of the genome } \\
\text { Regulates cell cycle arrest, apoptosis, senescence and DNA repair } \\
\text { Mutation frequency rises in therapy-related and complex karyotype AML } \\
\text { (approximately 70\%) } \\
\text { Mutations associated with absence of clinical remission, poor OS and DFS } \\
\text { Majority of mutations in the region encoding the DNA-binding domain } \\
\text { Mutations typically heterozygous followed by a rapid loss of heterozygosity } \\
\text { Mutually exclusive with NPM1, FLT3,MDM2 and ARF } \\
\text { Associated with -5, - - , -17 cytogenetic abnormalities } \\
\text { In presence of wild-type form, several inactivating processes including MDM2 } \\
\text { and MDMX overexpression, miRNA overexpression, FLT3-ITD mutations and } \\
\text { impact on TP53 pathway } \\
\text { Targeted therapy influenced by low frequency mutations } \\
\text { Therapy focused on reactivate the wild-type TP53 } \\
\text { Dual inhibitors of MDM2 and MDMX in clinical trials in AML } \\
\text { Combination therapies with BCL2 inhibitors (venetoclax) }\end{array}$ \\
\hline
\end{tabular}




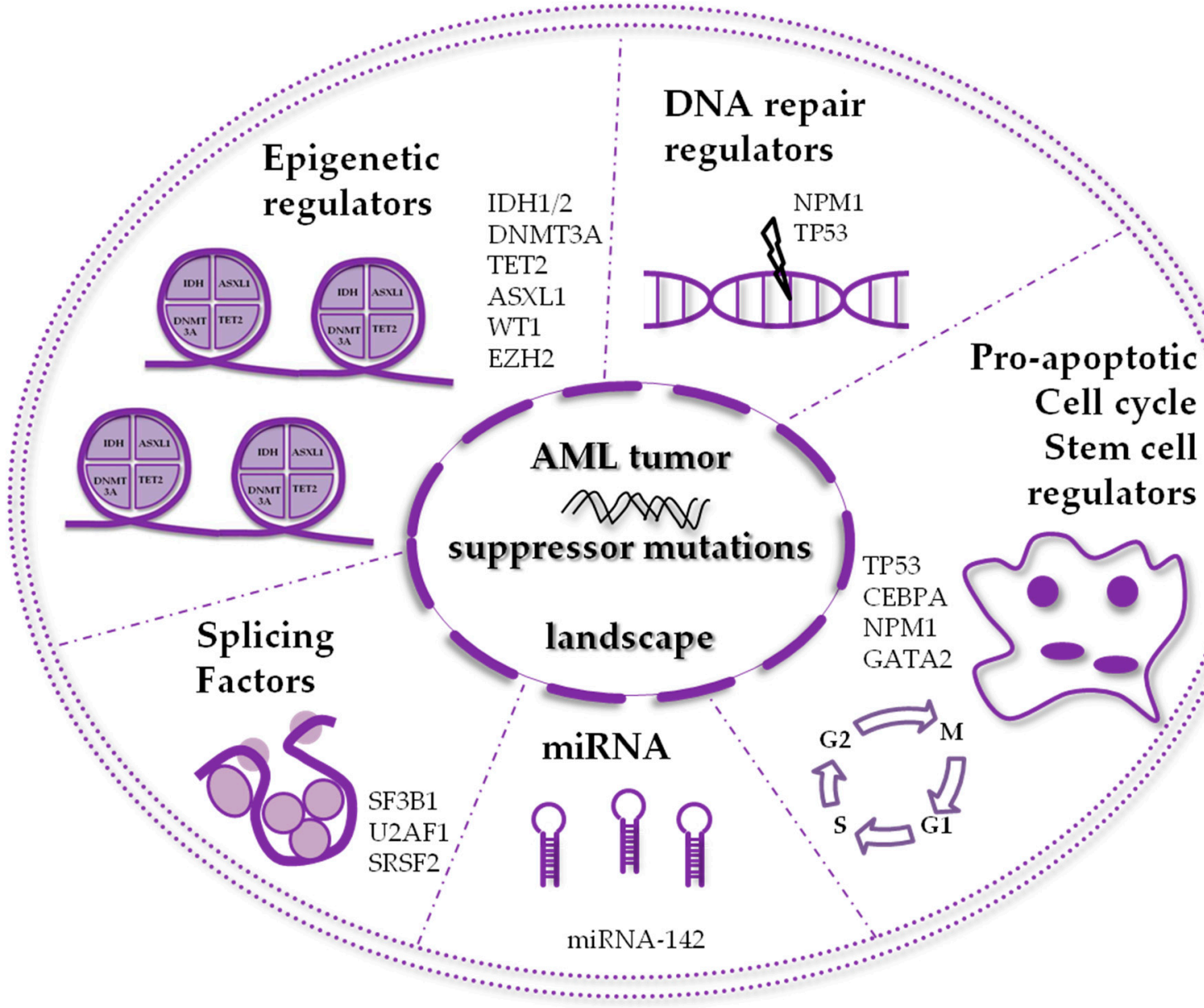

Figure 1. Schematic representation of the frequently mutated tumor suppressor proteins in acute myeloid leukemia (AML).

\section{AML Mutated Tumor Suppressors Involved in Epigenetic Mechanisms}

In this first section, we highlight tumor suppressors commonly mutated in AML, whose function, when mutated, is to deregulate epigenetic mechanisms.

\subsection{IDH1 and IDH2 Mutations}

Isocitrate dehydrogenase (IDH) is an enzyme that catalyzes the oxidative decarboxylation of isocitrate in ketoglutarate (KG), an irreversible reaction of the tricarboxylic acid cycle (TCA). There are three forms, located on three different chromosomes, with different intracellular localization and coenzymes interactions: IDH1 is located within cytoplasm and peroxisomes and is $\mathrm{NADP}^{+}$-dependent, while IDH2 and IDH3 are mitochondrial enzymes, with the first being $\mathrm{NADP}^{+}$- and the second $\mathrm{NAD}^{+}$-dependent [18]. Missense mutations associated with different solid and blood tumors have been identified for IDH1 and IDH2, but not for IDH3. These mutations were initially identified in gliomas [19], and later in AML [20], occurring at specific arginine residues within the catalytic active sites of the enzymes: mutations of IDH1 affect codon R132, with a single amino acid substitution from arginine to histidine, cysteine, serine, glycine, leucine or isoleucine, while mutations of IDH2 involve residues R140 or R172, where they commonly cause a change from arginine to glutamine or lysine, respectively, but other amino acid substitutions are possible [21]. The result of these mutations is a neomorphic activity of the enzyme that causes the formation of D-2-hydroxyglutarate (2-HG), a metabolite with oncogenic properties [22]. Its accumulation inhibits various $\alpha-K G$-dependent dioxygenases involved in epigenetic regulation, including those responsible for histones and DNA demethylation, such as TET1/2 
methylcytosine hydroxylases (Table 2, Figure 2) [23-25]. Consistently, TET2 inactivation is mutually exclusive with IDH1 and IDH2 mutations [26]. The hypermethylation induced by IDH1 and IDH2 mutations results in cell differentiation arrest [23]. Rare cases of patients bearing both IDH1 and IDH2 mutations have been reported [27]. In AML, IDH1 and IDH2 mutations are found in about $10 \%-30 \%$ of patients, with a higher frequency in patients with cytogenetically normal AML (CN-AML) [18]. Prognosis of patients harboring mutations in IDH1 and IDH2 is generally poor [7], with an increased probability of relapse [28]. Prognosis could be even worse, with a decreased overall survival (OS), when patients bear other mutations, such as NPM1, FLT3, DNMT3A, ASXL1, RUNX1, and NRAS. For this reason, IDH1 and IDH2 mutational status alone is not useful to define prognosis [18]. On the other hand, some studies suggest that IDH1 and IDH2 mutations could contribute to progression from MDS or MPN to AML, through a mechanism of reactive oxygen species (ROS) accumulation and DNA damage leading to stabilization and activation of HIF-1 [29-31]. Recently, the Food and Drug Administration (FDA) approved IDH1 and IDH2 inhibitors ivosidenib and enasidenib for the treatment of adult relapsed or refractory AML with IDH1 and IDH2 mutations [25].

\subsection{DNMT3A Mutations}

The de novo methyl transferase 3A (DNMT3A) gene encodes for a highly conserved 130-kDa protein involved in epigenetic regulation [32,33]. DNMT3A can be found in the nucleus as dimer, tetramer, or larger structures, and it regulates gene expression through methylation of the cytosine residue of CPG islands [34,35]. Mutations in DNMT3A were originally identified in AML patients in 2010 [36] and subsequently in other adult hematological cancers, often arising as early event in AML pathogenesis $[17,37,38]$. Most of DNMT3A mutations found in hematological cancers are located within the methyltransferase domain, with a higher prevalence (about $65 \%$ ) of heterozygous missense mutations at codon R882 [12,36,38-40]. The most common mutation is R882H, that has been proven to act as a dominant-negative on the wild-type DNMT3A [41-43], losing the ability to form homotetramers [41,43] and thus reducing the methytransferase activity (Table 2, Figure 2). This could explain the DNA hypomethylation observed in patients carrying this type of mutation [12,44-46]. DNMT3A mutations are found in $15 \%-30 \%$ of patients with de novo AML and are also found in AML evolving from MDS or $\mathrm{Ph}^{-}$MPNs $[36,38,40,47,48]$. Compared to wild-type patients, those carrying R882 mutations are generally diagnosed with $\mathrm{CN}-\mathrm{AML}$ with myelomonocytic or monocytic blast morphology, with a higher white blood cell (WBC) count and advanced age [39,40,48,49]. DNMT3A-mutated AMLs frequently harbor other mutations, such as NPM1 and FLT3 mutations $[12,39,40]$. Prognosis of patients harboring DNMT3A R882H mutation seems to be worse than for patients with wild-type DNMT3A, although large prospective studies are not available yet. Until then, to define the prognosis of these patients, other validated parameters should be considered, such as age, cytogenetic abnormalities, minimal residual disease (MRD) and presence of other mutations. Furthermore, DNMT3A-mutated cells are still present in AML patients with long-lasting complete remission, and this is consistent with the idea that epigenetic mutations, in this case DNMT3A mutations, could be preleukemic events, raising the question of whether DNMT3A should be used to monitor MRD [17,50,51]. This could also support the idea that additional mutations arising as a second hit in a preleukemic DNMT3A-mutated clone could be in some cases responsible for relapse [52]. 


\section{Histone demethylation}
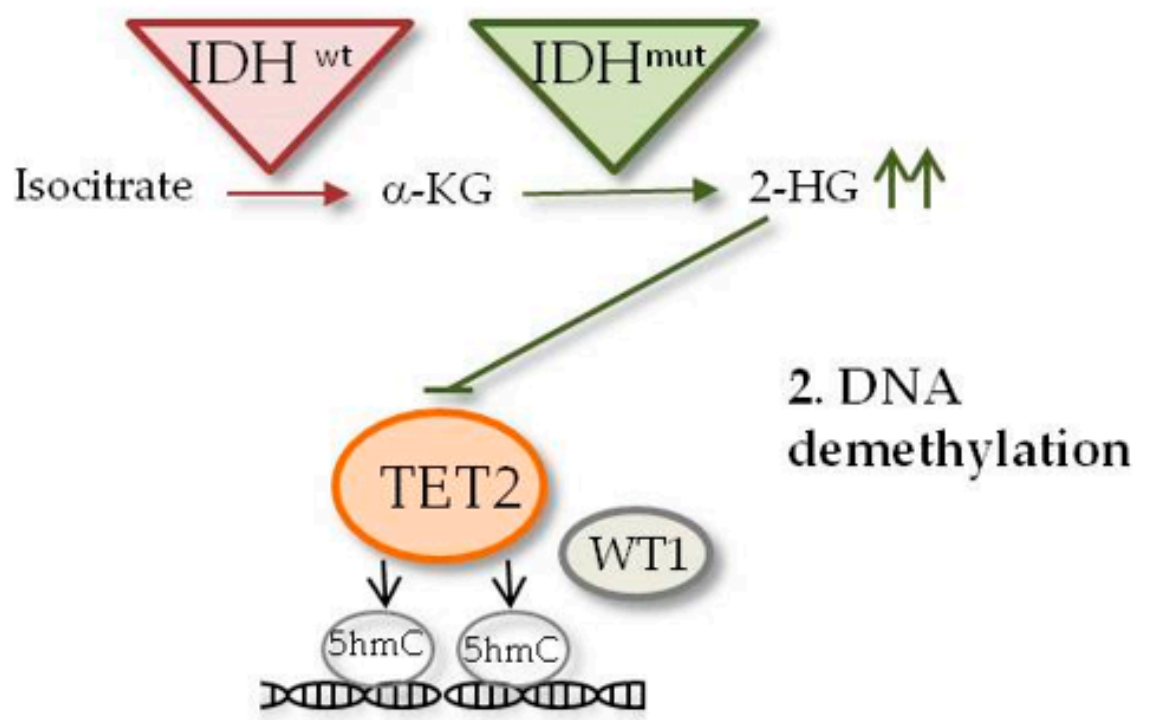

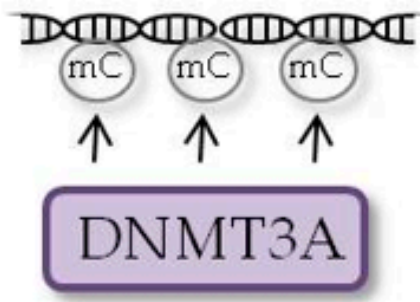

\section{DNA methylation}

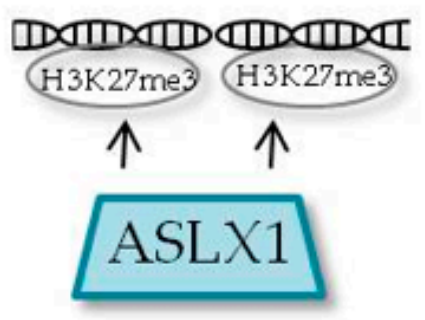

\section{Histone modification}

Figure 2. Epigenetic regulators commonly mutated in AML. This scheme highlights the network of proteins involved in epigenetic activity, divided in four epigenetic levels: (1) histone demethylation, (2) DNA demethylation, (3) DNA methylation and (4) histone modification. In detail, (1) and (2) highlight the dynamic interplay between IDH1/2, TET2 and WT1: mutated IDH1 and IDH2 inhibit the activity not only of various histone demethylases, but also of DNA demethylase TET2, through the generation of oncometabolite 2-HG, in turn resulting in DNA hypermethylation; mutated TET2 loses the demethylating activity and causes a hypermethylation profile for itself; mutated WT1is unable to interact with TET2, impairing TET2 demethylating activity. (3) Mutated DNMT3A loses the methyltransferase ability, thus resulting in DNA hypomethylation. (4) Mutated ASXL1 loses the ability to methylate histone $\mathrm{H} 3$ via PRC2 complex, causing a deregulation of key genes involved in stem-cell maintenance and myeloid differentiation. $\alpha$-KG, $\alpha$-ketoglutarate; 2-HG, 2-hydroxyglutarate; 5hmC, 5-hydroxymethylcytosine; mC, methylcytosine; H3, histone H3; K27me3, trimethyl at 27th lysine residue.

\subsection{TET2 Mutations}

Ten-eleven translocation-2 (TET2) is a protein involved in epigenetic regulation, as it controls hydroxymethylation by converting 5-methylcytosine to 5-hydroxymethylcytosine, leading to DNA demethylation [53]. TET2 is important during hematopoiesis, as it promotes self-renewal of HSCs, lineage commitment and terminal differentiation of monocytes [54]. Expression of TET2 gene variants 
in myeloid cancers was established for the first time in 2009 [55]. TET2-inactivating mutations result in a decrease of 5-hydroxymethylcytosine, and this parameter has been proposed as a potential diagnostic and prognostic marker for hematological cancers (Table 2, Figure 2) [56]. TET2 mutations are very heterogeneous, including frame shifts, nonsense and missense mutations and in-frame deletions, and can be homo- or heterozygous [53]. Both homo- and heterozygous mutations in the TET2 gene can be found in hematological cancers in patients with similar clinical signs and no difference in OS [57], although patients with homozygous mutations show an inferior event-free survival (EFS) and a higher relapse rate [58]. The frequency of TET2 mutations in AML patients is about $12 \%-34 \%$ [59]. They occur early during the pathogenesis and could collaborate with other mutations to promote different hematological cancers [53]. TET2 mutations are associated with CN-AML or intermediate-risk cytogenetic abnormalities and with increased age, higher WBC and blast counts, low platelet count and FLT3-ITD, NPM1 and ASXL1 mutations, but are mutually exclusive with IDH1 and IDH2 mutations [7,53]. Clearly, different combinations of TET2 and other gene mutations will foresee different outcomes, and the prognostic value of TET2 mutations remain controversial [60]. Recently, with the introduction in the clinical practice of hypomethylating agents (HMAs), such as azacitidine and decitabine, in adverse-risk-group patients, it seems that the clinical prognosis of patients bearing TET2 mutations could be improved, since the presence of these mutations could foresee a more favorable response to this type of treatment [53].

\subsection{WT1 Mutations}

Wilms tumor 1 (WT1) is a tumor suppressor gene responsible for the development of familiar Wilms' tumor, from which it takes its name [61,62]. WT1 gene encodes for a transcription factor that contains four zinc finger motifs at the C-terminal and a DNA-binding domain rich with proline-glutamine at the N-terminal [63]. It is involved in regulation of cell survival, proliferation and differentiation [61,64]. There are four major isoforms of WT1, deriving from two different splicing events: the first causes a 17 amino acid insertion in exon 5 and the second inserts three amino acids at the end of exon 9, leading to a decreased DNA-binding and transcription factor ability and an increased RNA binding $[65,66]$. Some studies demonstrated that differential expression of isoforms may have a clinical significance in AML [67]. In normal hematopoiesis, WT1 expression is detectable in CD34 ${ }^{+} \mathrm{CD} 38^{-}$population, while in other populations, WT1 levels are low, suggesting a role in self-renewal of quiescent cells [68,69]. WT1 was found overexpressed in AML patients [70], leading to chemotherapy resistance, decreased OS and higher relapse incidence when chemotherapy fails in reducing its expression levels [62,71]. In addition to this oncogenic role, several mutations in WT1 gene can be found in $6 \%-15 \%$ of de novo AML, including amino acid substitutions, deletions and insertions, and usually occur in exons 1, 7 and 9 [72]. These mutations are frequently nonsense, and the resulting truncated protein can be either expressed or degraded via nonsense-mediated decay [73]. WT1 mutations are often found in younger patients and correlate with FLT3-ITD and CEBPA biallelic mutation [72,74]. Analysis of a large cohort of AML patients $[11,75]$ revealed that WT1 mutations anticorrelate with TET2 and IDH1/2 mutations, suggesting that WT1 may have a role in the same epigenetic pathway [76]. Promoter DNA methylation microarrays on the same cohort demonstrated a hypermethylation pattern and 5-hmC levels reduction in patients with WT1 mutations, a signature very similar to those bearing mutations in TET2 and IDH1/2 genes [76], probably due to the ability of WT1 to directly interact with TET2 and TET3. Indeed, WT1 mutations result in a loss of TET2 function (Table 2, Figure 2) [76,77]. Given the epigenetic alterations due to WT1 mutations, the use of HMAs such azacitidine is being explored as a potential strategy of therapy in WT1-mutated patients [62]. Moreover, WT1 mutations are usually associated with a negative prognostic outcome and resistance to conventional chemotherapy [78]. Finally, the significance of some polymorphisms has also been investigated, among which the role of SNP rs16754 has been highlighted as a positive prognostic factor in patients with AML [79,80]. 


\subsection{ASXL1 Mutations}

The additional sex combs-like 1 (ASXL1) gene on 20q11 chromosome encodes for a polycomb chromatin-binding protein which acts as an enhancer of the trithorax and polycomb genes [81,82]. It is homolog of the additional sex combs (Asx) gene of Drosophila [83], where it plays a crucial role in embryo development and in the determination of segment identity. ASXL1 acts as an epigenetic scaffold protein by binding to chromatin and recruiting polycomb repressive complex 2 (PRC2), consisting of EZH2, EED and SUZ12 [84]. In this way it regulates the expression pattern of genes involved in both hematopoietic and non-hematopoietic systems [85]. It was firstly identified as a coactivator of retinoic acid receptor (RAR), and among its targets are the HOX genes [86]. It is involved in histone modifications, such as histone $\mathrm{H} 3$ tri-methylation at 27th lysine residue (H3K27me3) [87], and directly interacts with histone modifiers including NCOA1 (histone acetyltransferase) and LSD1 (histone demethylase) [88]. It was already detected as a component of the PR-DUB complex, related to the deubiquitination of histone H2A [89]. Mice models carrying ASXL1 mutation showed myeloid dysplasia and shorter survival, mainly due to PRC2 inactivation [90]. Mutations in the ASXL1 gene have been described in many subtypes of myeloid malignancies and are associated with adverse prognosis, shorter OS and higher risk of progression $[88,91]$. The frequency is slightly different between single groups. The highest percentage of mutated patients can be found in chronic myelomonocytic leukemia (CMML), followed by myelofibrosis, secondary AML, MDS and de novo AML, with frequencies of about $50 \%, 35 \%, 30 \%$, $15 \%$ and $8 \%$, respectively [92,93]. Acquired ASXL1 mutations are frequently frameshift and nonsense, around the Gly-rich domain (amino acids 642-685) on exon 12, and cause the expression of truncated ASXL1, with loss of the PHD domain, crucial for the regulation of key genes involved in stem-cell maintenance and myeloid differentiation (Table 2, Figure 2) [94]. The most common is in position G646. The incidence of ASXL1 mutations increases significantly with age and correlates with $\mathrm{t}(8 ; 21)$, trisomy $8(+8)$ and $\operatorname{del}(7 \mathrm{q}) /-7$ chromosomal aberrations $[95,96]$. Otherwise, ASXL1 mutations are frequently associated with other mutations, such as RUNX1 and IDH2, conferring poor prognosis, far less with FLT3 and NPM1 mutants [96,97]. Furthermore, an epigenetic drug screening demonstrated a hypersensitivity of ASXLl mutant cells to BET bromodomain inhibitors [98]. Lastly, ASXL1 is one of the fusion protein partners of PAX5 in B-cell acute lymphoblastic leukemias [99].

\section{AML Mutated Tumor Suppressors Involved in Non-epigenetic Mechanisms}

In this second section, we describe other frequently mutated AML tumor suppressors whose function is not involved in epigenetic mechanisms.

\subsection{NPM1 Mutations}

The gene nucleophosmin (NPM1), located on 5q35, encodes a nucleus-cytoplasm shuttling protein [100]. In 2005, an unusual cytosolic localization was identified and associated with the presence of mutations [101]. Functionally, NPM1 is involved in the regulation of several cellular processes such as centrosome duplication [102], DNA repair [103], ribosomal protein assembly and apoptotic response to oncogenic stimuli [103]. NPM1 is a key regulator of tumor suppressors TP53 and p19ARF [104,105], thus contributing to modulate growth-suppressive pathways. Mutations are typically heterozygous and mostly located in exon 12 (Table 3, Figure 3) [106]. They lead to an insertion of four nucleotides determining an open reading frameshift which in turn generates a de novo nuclear export signal $[106,107]$. As a result, the nucleolar localization signal is lost and the protein relocalizes within the cytoplasm [101]. Furthermore, NPM1 mutants (NPM1c) acquire the ability to impound the wild-type form, preventing the NPM1 wild-type tumor suppressor functions [108]. Mouse models of mutated NPM1 (NPM1c) support the importance of NPM1c as a cooperative event in leukemogenesis, but not to initiate leukemia [109]. The impact of NPM1 mutations on prognosis has been extensively examined over the last decade. They can be found in $25 \%-30 \%$ of AML patients, and their frequency rises in adult AML (near 30\%-40\%), especially CN-AML [101,110]. Patients with this genotype are 
classified as favorable risk [111] in the absence of concomitant FLT3-ITD mutations, correlating with good response to conventional therapy and high complete remission rates, EFS and/or OS [11,112]. Risk associated to NPM1 mutations deserves a more accurate evaluation when occurring with FLT3 (fms-related tyrosine kinase 3) mutations. Indeed, co-occurrence of NPM1 and FLT3, either when the latter harbors the more common ITD or the less frequent D835 point mutations, significantly improves the response and the survival outcomes over that of an isolated FLT3 mutation, thus defining a highly favorable prognostic AML group [113]. Furthermore, the level of NPM1 mutations is generally used for monitoring MRD [114,115]. Interestingly, the co-occurrence of NPM1 and FLT3 mutations is consolidated [112], with a frequency near to twice that of correlation with the wild-type form, suggesting a direct molecular link between them, which has not yet been investigated. This combination is associated with an intermediate prognosis [116]. Moreover, DNMT3A, IDH1, IDH2 and TET2 mutations are identified as concomitant to NPM1 mutations [12,117], confirming the dynamic interplay among AML tumor suppressors. Finally, NPM1 may be involved in chromosomal translocations with ALK $(\mathrm{t}(2 ; 5)(\mathrm{p} 23 ; \mathrm{q} 35))$, which represents the anaplastic large-cell lymphoma molecular landmark [118] and with $R A R-\alpha(t(5 ; 17)(q 35 ; \mathrm{q} 21))$, causing a subtype of acute promyelocitic leukemia (APL) [119].
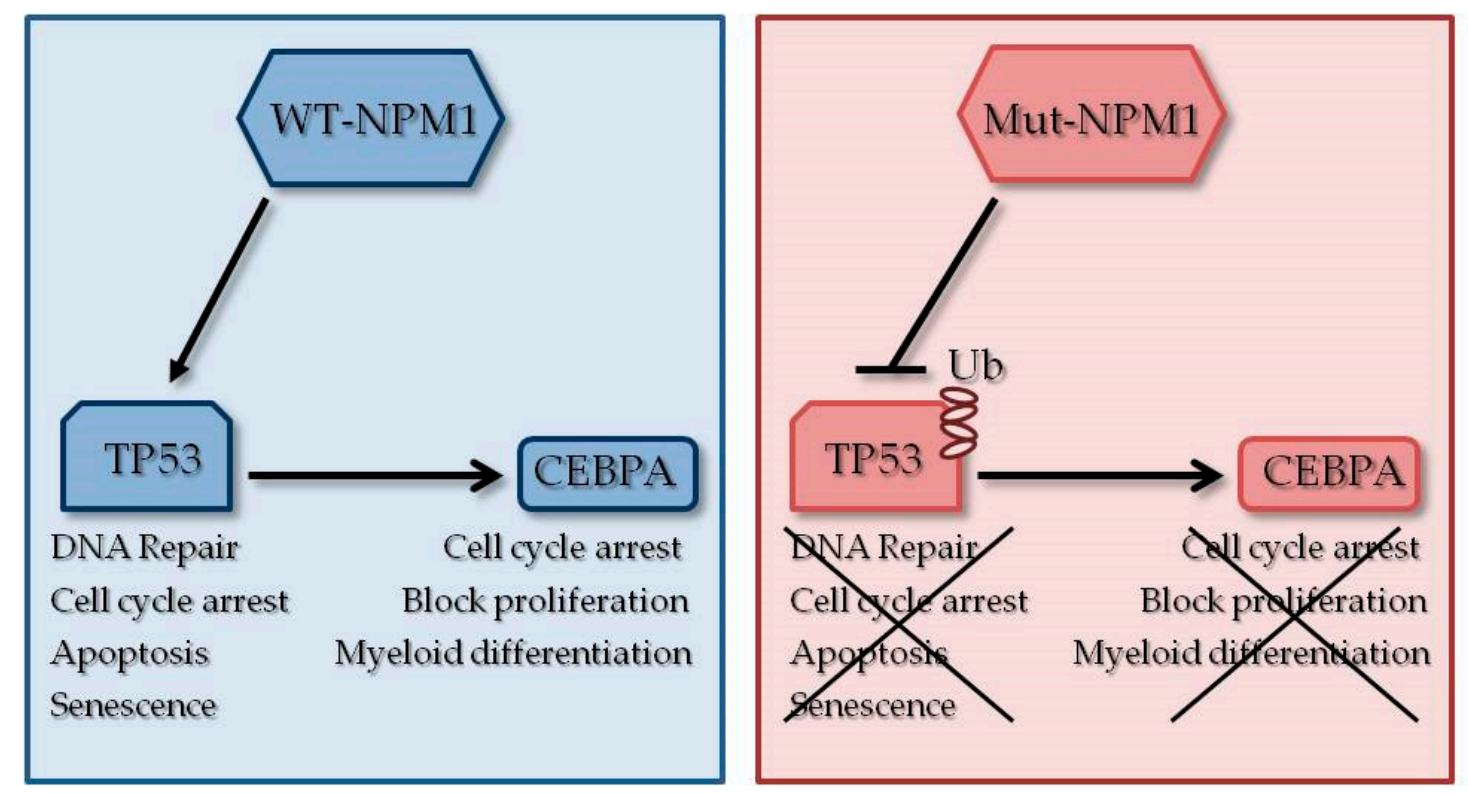

Figure 3. Relevant mutated non-epigenetic tumor suppressors in AML. This scheme highlights proteins' interaction and pathway deregulation in AML blast with known tumor suppressors mutations. The blue panel shows, in detail, the positive interplay involving wild-type NPM1, increase in TP53 stability (via Mdm2 ubiquitin-ligase activity inhibition) and in CEBPA activity. The red panel shows how, in presence of mutated NPM1, TP53 is highly ubiquitinated, degraded and is unable to activate CEBPA.

\subsection{CEBPA Mutations}

CEBPA, an intronless gene on chromosome 19q31.1, encodes for a zinc finger transcription factor [120], which plays a pivotal role in the differentiation of multipotent precursor cells into myeloid progenitors [121]. In particular, by an advanced interplay between the activation of transcription of myeloid differentiation and inhibition of myeloid proliferation genes, it directs towards granulocyte and monocyte differentiation. CEBPA recognizes the CCAAT sequence on the promoters of target genes and by the interaction with CEBPB and CEBPC activates their functions. The genes directly regulated by CEBPA are divided into four big categories: growth factor receptors, transcription factors (PU.1, c-Jun, c-Myc, SOX4 and E2F), primary and secondary granule proteins and microRNAs (miR-223, miR-34 and miR-30) [122]. Recently CEBPA has been described for its ability to control self-renewal properties of hematopoietic stem and progenitor cells (HSPCs) [123]. Moreover, knockout mice for CEBPA or 
with a mutation in the CEBPA basic region displayed a complete block of myeloid differentiation and increased levels of hematopoietic stem cells [124]. The possibility of using two different types of start codons (AUG and an alternative in frame GUG) gives rise to two protein isoforms called p42 and p30 [125]. The second isoform is smaller than the first, without the N-terminal domain that is crucial to promote proliferation arrest by direct inhibition of E2F transcription factors. Moreover p30 exhibits a dominant-negative effect over p42 isoform [125]. The ratio of $\mathrm{p} 30 / \mathrm{p} 42$ is critical for a correct granulopoiesis. For this reason, levels of the two isoforms are tightly controlled at the translational level in response to extracellular conditions [126]. Mutations in CEBPA gene occur in 5\%-20\% of de novo AML [127], in both the $\mathrm{C}$ and the $\mathrm{N}$ terminals of the gene. In-frame insertions or deletions in C-terminal mutations of CEBPA disrupt the DNA-binding and homodimerization domains, while out-of-frame insertions or deletions in the $\mathrm{N}$-terminal result in abolishing the translation of full length CEBPA, leading to overexpression of the shorter $\mathrm{p} 30$ isoform [126].The peculiarity of these mutations is that they are frequently biallelic, and this feature was associated with favorable prognosis if compared to cases with single allele mutation [128]. Results obtained from gene expression profiling confirmed a peculiar signature associated with biallelic CEBPA mutations, therefore the $2016 \mathrm{WHO}$ classification of myeloid neoplasms defined it as a distinct diagnostic entity [129]. Multiple mechanisms for CEBPA inhibition have been identified in leukemic cells, from genetic to epigenetic, from transcriptional to translational and post-translational levels (Table 3, Figure 3). Mutations of CEBPA are also associated with mutations in TET2, the most frequently co-mutated gene (34\%), followed by GATA2 (21\%), WT1 (13\%), DNMT3A (9\%) and ASXL1 (9\%) [130-133]. Recently, a direct co-occurrence between CEBPA and granulocyte colony-stimulating factor receptor (CSF3R) mutations has been reported [134,135]. Notably, near $30 \%$ of patients with CEBPA biallelic mutations feature a CSF3R mutation; in these patients the co-occurrence induces a worsening outcome [136,137].

\subsection{TP53 Mutations}

Tumor protein 53 (TP53) is a tumor suppressor gene located on chromosome 17p13.1. It regulates cell cycle arrest, apoptosis, senescence and DNA repair. It has been initially described as "the guardian of the genome" referring to its role in preserving genome stability through the prevention of mutations [138]. The encoded protein is characterized by three main domains: an N-terminal transcription-activation domain (TAD), which activates further transcription factors; a central DNA-ligand domain (DNA-binding core domain DBD) enriched in zinc $\mathrm{Zn}^{+}$ions and arginine amino acid residues; and a C-terminal homo-oligomerization domain (OD) [139]. More than 50\% of human tumors carry TP53 mutations, including hematological malignancies, where it has been observed mutated in 5\%-20\% of AML patients [12]. However, in therapy-related AML and in those with complex karyotype, the rate of TP53 mutations or deletions increases dramatically (approximately 70\%) [140,141]. TP53 mutations are associated with resistance to chemotherapy, poor OS and poor disease-free survival (DFS) [142,143]. The sharp association with complex karyotype confirms TP53 as a pivotal guard of genome stability [144,145]. TP53 is also involved in the regulation of stem cell quiescence and self-renewal by directly interacting with telomerase [146]. Thus, the malignant clone may benefit from the presence of a TP53 mutated form that accelerates the ability of leukemia stem cells to proliferate after therapy, to accumulate mutations and to become resistant [142,143]. The vast majority of TP53 mutations occur in the region encoding the DNA-binding domain. Notably, six mutational hot-spots residues were identified R175, G245, R248, R249, R273 and R282, with R273 and R248 being the most frequently mutated [142,147]. Mutations are typically heterozygous, however they are usually followed by a rapid loss of heterozygosity (LOH) due to the high instability of $\mathrm{TP53}^{+-}$clones [148]. They are mutually exclusive with other mutated genes (NPM1, FLT3, MDM2 and ARF) [12,149] but commonly co-occur with del(5q), del(7q) and del(17p) cytogenetic abnormalities $[140,141,148,149]$. Finally, TP53 pathway may be altered also in presence of wild-type TP53 by several inactivating processes including MDM2 and MDMX overexpression [149,150], miRNA overexpression (e.g., miR-3151, miR-125b) and FLT3-ITD mutations, which also promote TP53 inactivation. Additional aberration including SIRT1 overexpression with subsequent TP53 
deacetylation, CRM1 overexpression and nuclear export of TP53, destruction of TP53 regulator PML in PML-RAR $\alpha$ positive AMLs and NPM1 mutations via dysregulation of ARF-MDM2-TP53 axis [150-153] can affect TP53 pathway (Table 3, Figure 3). The pivotal role of TP53 led to the development of targeted therapies with the aim of reactivating TP53 function. Dual inhibitors of MDM2 and MDMX have been developed and used in clinical trials [150]. Finally, combination therapies with BCL2 inhibitors and TP53 activators might be promising, taking into account the ability of TP53 to regulate MCL-1 degradation [154].

\section{Other Relevant Mutated Tumor Suppressors}

In this last section we will discuss other mutations, with high relevance in leukemogenesis but that occur less frequently in the AML mutational landscape.

\subsection{EZH2 Mutations}

The enhancer of zeste 2 (EZH2) gene encodes for a catalytic component of the polycomb repressive complex 2 (PRC2), and its role in epigenetic regulation is enacted through di- and trimethylation of lysine 27 of histone $\mathrm{H} 3$, thus leading to transcriptional repression. In normal hematopoiesis, EZH2 is involved in maintaining multipotency and self-renewal of HSCs [84,155]. Low EZH2 protein levels in AML can be due to inactivating mutations in about 2\% of adult AML [156], but more often this decrease is dependent on post-translational dysregulation of the protein, triggered by EZH2 phosphorylation induced by CDK1 and subsequent proteasomal degradation. Another mechanism responsible for decreased EZH2 levels in AML is the 7q chromosomal deletion (-7), since EZH2 gene is located on this chromosome arm and these patients are often resistant to chemotherapy and characterized by a poor prognosis [84,156], Finally, splicing alteration due to mutations in genes involved in the splicing machinery, including SRSF2 and U2AF1 (near 10\% of AML patients) decreases EZH2 transcript $[155,157]$. For this reason, U2AF1 and inactivating EZH2 mutations are mutually exclusive [157].

\subsection{Splicing Factors Mutations}

Splicing factors (SFs), notably SF3B1, U2AF1 and SRSF2, are well established mutated genes in MDS, with different frequency (45-85\%) depending on their subtypes [158-160]. The impact on prognosis of these mutations in AML is poorly investigated. Only one study of Hsin-An Hou et al. performed on 500 adult de novo AML outlines near $10 \%$ incidence of SFs mutations, all located in hotspot areas [161]. They identified a correlation with intermediate-risk cytogenetics, with RUNX1, ASXL1, IDH2 and TET2 mutations, and they found an association with poor prognosis in term of shorter DFS and OS.

\section{3. miRNA Mutations}

miRNA play a pivotal role in sustaining AML by dysregulating several processes such as proliferation, apoptosis, quiescence and disease progression [162,163]. It is well established that their expression level may affect miRNA functions, making them feasible biomarkers for predicting prognosis [164]. Downregulation of many of them induces changes in DNA methylation (miR-29), cell proliferation (miR-34, miR-146a, miR-223, miR-9), growth (miR-29, miR-139-5p, miR-193a, miR-22), differentiation (miR-223, miR-34, miR-193a, miR-9, miR-22) and eventually apoptotic rate (miR-34c-5p, miR-193a, miR-223) as a result of overexpression of their target genes [165-169]. miRNA nucleotide mutations are relatively rare in AML. In one study by Trissal et al., miRNA 142-3p arises as the only recurrently mutated miRNA in TCGA AML dataset, with a frequency of $2 \%$ [170]. These mutations reduce miR-142-3p and miR-142-5p levels and contribute to increase the expression of Hoxa9/a10 target genes in myeloid committed compartment. 


\subsection{GATA2 Mutations}

The GATA2 gene encodes for a transcription factor involved in the regulation of hematopoietic stem cell activity and self-renewal [171] and in myeloid and erythroid progenitor cell differentiation [172]. GATA2 mutations are identified in MDS [173] in blast crisis of chronic myeloid leukemia (CML) [174]. In addition, GATA2 gene mutations are also found in de novo AML [175,176], being mainly concentrated within the exon 3 which encodes for the zinc finger domain 1, with a frequency near to $4 \%$, which rises to $12 \%$ in the FAB M4 subtype [177]. Interestingly, GATA2 mutations are often associated with CEBPA biallelic mutations and, with lower incidence, to NPM1 and FLT3 mutations $[176,178]$. Furthermore, patients harboring both CEBPA biallelic and GATA2 mutations show a more favorable prognosis and better OS than those with CEBPA biallelic mutations alone [175]. Curiously, germline GATA2 mutations frequently occur in Emberger syndrome, in monocytopenia and mycobacterial infection (MonoMAC) and in secondary AML [179-181].

\section{Conclusions}

The genetic heterogeneity of AML patients and the coexistence of multiple subclones are usually the most common cause of relapse. Nowadays, nearly 50\% of AML patients relapse after the first cycle of induction chemotherapy. Additional genetic changes might arise, thus leading to the selection of novel resistant subclones. Furthermore, due to their plasticity, subclones can easily adapt and escape standard treatments. The accurate identification of mutated genes is currently considered important for patients' stratification and, as a consequence, for therapeutic decisions. In recent years many efforts were addressed to ascertain AML potential targets associated with either resistance to therapy or disease relapse. With the advent of mass-spectrometry-based methods performed directly on human AML-sorted stem cells, a significant number of leukemia-specific proteins, especially membrane-associated, have been identified. The main objective of this approach has been the identification of novel AML stem cell biomarkers to exploit as immunotherapeutic targets, in order to eradicate the disease [182-185]. Moreover, patients' proteomic profiles could correlate with the mutational status and thus with the prognosis of AML patients, suggesting that proteogenomic approaches might become the main goal in the near future. In terms of next-generation sequencing (NGS), the establishing of an accurate genetic profile at the onset of the disease has allowed designing tailored therapies aiming to eradicate residual mutated clones. In clinical practice, the detection of tumor suppressor gene mutations is performed not only for the diagnosis but also to control and measure MRD. Indeed, the risk of relapse is sharply related to the persistence of MRD after chemotherapy. Gene mutation profile has affected not only the prognosis, as in the case of the co-occurrence of NPM1 and FLT3, but also the choice of treatment, since some of them become therapeutic targets (e.g., IDH1/2, WT1 and TET2) (Table 4). In addition, some epigenetic regulators (DNMT3A, TET2, ASXL1) come out as age-related mutated genes in healthy elderly subjects, an event known as age-related clonal hematopoiesis. Therefore, they have become relevant to predict the onset of hematologic malignancies but not to monitor the MRD. In conclusion, further studies are still needed in order to explore the dynamic interplay between tumor suppressors, oncogenes and persistence of mutations, to help clarify patients' classification and determine who might benefit from additional therapeutic strategies. 
Table 4. Summary of the impact of tumor suppressor genes mutation on prognosis and recommendations for clinical testing.

\begin{tabular}{|c|c|c|c|}
\hline Mutated Gene & & Prognosis & Current Diagnostic Practice ${ }^{1}$ \\
\hline ASXL1 & Poor & $\begin{array}{c}\text { Worse OS } \\
\begin{array}{c}\text { Correlation with age }>60 \text { years and } \\
\text { higher WBC counts }\end{array}\end{array}$ & $\begin{array}{l}\text { Recommended by } 2017 \text { ELN } \\
\text { guidelines }\end{array}$ \\
\hline CEBPA & Variable & $\begin{array}{c}\text { Positive in CN-AML } \\
\text { Biallelic mutations have better EFS, DFS } \\
\text { and OS } \\
\text { Single mutations with } \\
\text { NPM1mut/FLT3-ITD }{ }^{\text {low }} \text { cases have } \\
\text { worse OS compared with CEBPA } \\
\text { wild-type NPM1mut/FLT3-ITD }{ }^{\text {low }} \text { cases } \\
\text { Impaired outcome with concurrent } \\
\text { TET2 mutation } \\
\text { Better OS with concurrent GATA2 } \\
\text { mutation }\end{array}$ & $\begin{array}{l}\text { Recommended by } 2017 \text { ELN } \\
\text { guidelines }\end{array}$ \\
\hline DNMT3A & Poor & Linked to adverse outcomes & $\begin{array}{l}\text { Recommended: pre-leukemic } \\
\text { event, could indicate higher } \\
\text { probability of relapse }\end{array}$ \\
\hline IDH1 & $\begin{array}{l}\text { Not consistent } \\
\text { data }\end{array}$ & $\begin{array}{l}\text { Impaired outcome in R132 mut/FLT3 } \\
\text { wild-type patients }\end{array}$ & $\begin{array}{c}\text { Recommended: new specific } \\
\text { inhibitor (ivosidenib) in clinical } \\
\text { trials }\end{array}$ \\
\hline IDH2 & $\begin{array}{l}\text { Not consistent } \\
\text { data }\end{array}$ & $\begin{array}{c}\text { R172 showed no correlation to outcome } \\
\text { or response } \\
\text { R140 improved OS and decreased } \\
\text { response rates }\end{array}$ & $\begin{array}{c}\text { Recommended: new specific } \\
\text { inhibitor (enasidenib) in clinical } \\
\text { trials }\end{array}$ \\
\hline NPM1 & Good & $\begin{array}{c}\text { Improved OS, DFS, and relapse-free } \\
\text { survival (RFS) }\end{array}$ & $\begin{array}{l}\text { Recommended by } 2017 \text { ELN } \\
\text { guidelines }\end{array}$ \\
\hline TET2 & $\begin{array}{l}\text { Not consistent } \\
\text { data }\end{array}$ & $\begin{array}{l}\text { Impaired OS in multivariate analysis } \\
\text { Impaired DFS }\end{array}$ & $\begin{array}{l}\text { Recommended: could respond } \\
\text { to HMAs treatment }\end{array}$ \\
\hline WT1 & Poor & $\begin{array}{l}\text { Often concurrent with FLT3 mutations } \\
\text { Impaired OS and RFS }\end{array}$ & $\begin{array}{l}\text { Recommended: could respond } \\
\text { to HMAs treatment }\end{array}$ \\
\hline TP53 & Poor & $\begin{array}{c}\text { Associated with resistance to } \\
\text { chemotherapy } \\
\text { Impaired OS and DFS } \\
\text { Association with complex karyotype }\end{array}$ & $\begin{array}{l}\text { Recommended by } 2017 \text { ELN } \\
\text { guidelines }\end{array}$ \\
\hline
\end{tabular}

Author Contributions: Conceptualization: C.P. and E.S.; writing and original draft preparation: C.P., E.S., C.C., J.P., and M.S.A.; writing, review and editing: E.B. and D.C. All authors have read and agreed to the published version of the manuscript.

Funding: The study was funded by AIRC.

Acknowledgments: The authors thank Jovanovski Aleksandar, Pergolizzi Barbara and Pironi Lucrezia for productive discussions and suggestions.

Conflicts of Interest: The authors declare no conflicts of interest.

\section{References}

1. De Kouchkovsky, I.; Abdul-Hay, M. Acute myeloid leukemia: A comprehensive review and 2016 update. Blood Cancer J. 2016, 6, e441. [CrossRef]

2. Grimwade, D. The changing paradigm of prognostic factors in acute myeloid leukaemia. Best Pract. Research. Clin. Haematol. 2012, 25, 419-425. [CrossRef] [PubMed]

3. Hartmann, L.; Metzeler, K.H. Clonal hematopoiesis and preleukemia-Genetics, biology, and clinical implications. Geneschromosomes Cancer 2019, 58, 828-838. [CrossRef] [PubMed]

4. Corces, M.R.; Chang, H.Y.; Majeti, R. Preleukemic Hematopoietic Stem Cells in Human Acute Myeloid Leukemia. Front. Oncol. 2017, 7, 263. [CrossRef] [PubMed] 
5. Shah, A.; Andersson, T.M.; Rachet, B.; Bjorkholm, M.; Lambert, P.C. Survival and cure of acute myeloid leukaemia in England, 1971-2006: A population-based study. Br. J. Haematol. 2013, 162, 509-516. [CrossRef]

6. Sill, H.; Olipitz, W.; Zebisch, A.; Schulz, E.; Wolfler, A. Therapy-related myeloid neoplasms: Pathobiology and clinical characteristics. Br. J. Pharmacol. 2011, 162, 792-805. [CrossRef] [PubMed]

7. Kavianpour, M.; Ahmadzadeh, A.; Shahrabi, S.; Saki, N. Significance of oncogenes and tumor suppressor genes in AML prognosis. Tumour Biol. J. Int. Soc. Oncodevelopmental Biol. Med. 2016, 37, 10041-10052. [CrossRef] [PubMed]

8. Lagunas-Rangel, F.A.; Chavez-Valencia, V.; Gomez-Guijosa, M.A.; Cortes-Penagos, C. Acute Myeloid Leukemia-Genetic Alterations and Their Clinical Prognosis. Int. J. Hematol. Oncol. Stem Cell Res. 2017, 11, 328-339.

9. de Jonge, H.J.; Huls, G.; de Bont, E.S. Gene expression profiling in acute myeloid leukaemia. Neth. J. Med. 2011, 69, 167-176.

10. Dohner, H.; Estey, E.; Grimwade, D.; Amadori, S.; Appelbaum, F.R.; Buchner, T.; Dombret, H.; Ebert, B.L.; Fenaux, P.; Larson, R.A.; et al. Diagnosis and management of AML in adults: 2017 ELN recommendations from an international expert panel. Blood 2017, 129, 424-447. [CrossRef]

11. Patel, J.P.; Gonen, M.; Figueroa, M.E.; Fernandez, H.; Sun, Z.; Racevskis, J.; Van Vlierberghe, P.; Dolgalev, I.; Thomas, S.; Aminova, O.; et al. Prognostic relevance of integrated genetic profiling in acute myeloid leukemia. N. Engl. J. Med. 2012, 366, 1079-1089. [CrossRef] [PubMed]

12. Cancer Genome Atlas Research, N.; Ley, T.J.; Miller, C.; Ding, L.; Raphael, B.J.; Mungall, A.J.; Robertson, A.; Hoadley, K.; Triche, T.J., Jr.; Laird, P.W.; et al. Genomic and epigenomic landscapes of adult de novo acute myeloid leukemia. N. Engl. J. Med. 2013, 368, 2059-2074. [CrossRef] [PubMed]

13. Shivarov, V.; Bullinger, L. Expression profiling of leukemia patients: Key lessons and future directions. Exp. Hematol. 2014, 42, 651-660. [CrossRef] [PubMed]

14. Welch, J.S.; Ley, T.J.; Link, D.C.; Miller, C.A.; Larson, D.E.; Koboldt, D.C.; Wartman, L.D.; Lamprecht, T.L.; Liu, F.; Xia, J.; et al. The origin and evolution of mutations in acute myeloid leukemia. Cell 2012, 150, $264-278$. [CrossRef]

15. Ding, L.; Ley, T.J.; Larson, D.E.; Miller, C.A.; Koboldt, D.C.; Welch, J.S.; Ritchey, J.K.; Young, M.A.; Lamprecht, T.; McLellan, M.D.; et al. Clonal evolution in relapsed acute myeloid leukaemia revealed by whole-genome sequencing. Nature 2012, 481, 506-510. [CrossRef] [PubMed]

16. Bullinger, L.; Dohner, K.; Dohner, H. Genomics of Acute Myeloid Leukemia Diagnosis and Pathways. J. Clin. Oncol. Off. J. Am. Soc. Clin. Oncol. 2017, 35, 934-946. [CrossRef] [PubMed]

17. Shlush, L.I.; Zandi, S.; Mitchell, A.; Chen, W.C.; Brandwein, J.M.; Gupta, V.; Kennedy, J.A.; Schimmer, A.D.; Schuh, A.C.; Yee, K.W.; et al. Identification of pre-leukaemic haematopoietic stem cells in acute leukaemia. Nature 2014, 506, 328-333. [CrossRef]

18. Lee, S.; Urman, A.; Desai, P. Emerging drug profile: Krebs cycle and cancer: IDH mutations and therapeutic implications. Leuk. Lymphoma 2019, 60, 2635-2645. [CrossRef]

19. Yan, H.; Parsons, D.W.; Jin, G.; McLendon, R.; Rasheed, B.A.; Yuan, W.; Kos, I.; Batinic-Haberle, I.; Jones, S.; Riggins, G.J.; et al. IDH1 and IDH2 mutations in gliomas. N. Engl. J. Med. 2009, 360, 765-773. [CrossRef]

20. Mardis, E.R.; Ding, L.; Dooling, D.J.; Larson, D.E.; McLellan, M.D.; Chen, K.; Koboldt, D.C.; Fulton, R.S.; Delehaunty, K.D.; McGrath, S.D.; et al. Recurring mutations found by sequencing an acute myeloid leukemia genome. N. Engl. J. Med. 2009, 361, 1058-1066. [CrossRef]

21. Waitkus, M.S.; Diplas, B.H.; Yan, H. Biological Role and Therapeutic Potential of IDH Mutations in Cancer. Cancer Cell 2018, 34, 186-195. [CrossRef] [PubMed]

22. Rakheja, D.; Medeiros, L.J.; Bevan, S.; Chen, W. The emerging role of d-2-hydroxyglutarate as an oncometabolite in hematolymphoid and central nervous system neoplasms. Front. Oncol. 2013, 3, 169. [CrossRef]

23. Figueroa, M.E.; Abdel-Wahab, O.; Lu, C.; Ward, P.S.; Patel, J.; Shih, A.; Li, Y.; Bhagwat, N.; Vasanthakumar, A.; Fernandez, H.F.; et al. Leukemic IDH1 and IDH2 mutations result in a hypermethylation phenotype, disrupt TET2 function, and impair hematopoietic differentiation. Cancer Cell 2010, 18, 553-567. [CrossRef] [PubMed]

24. Chowdhury, R.; Yeoh, K.K.; Tian, Y.M.; Hillringhaus, L.; Bagg, E.A.; Rose, N.R.; Leung, I.K.; Li, X.S.; Woon, E.C.; Yang, M.; et al. The oncometabolite 2-hydroxyglutarate inhibits histone lysine demethylases. EMBO Rep. 2011, 12, 463-469. [CrossRef] [PubMed]

25. Liu, X.; Gong, Y. Isocitrate dehydrogenase inhibitors in acute myeloid leukemia. Biomark. Res. 2019, 7, 22. [CrossRef] [PubMed] 
26. Gaidzik, V.I.; Paschka, P.; Spath, D.; Habdank, M.; Kohne, C.H.; Germing, U.; von Lilienfeld-Toal, M.; Held, G.; Horst, H.A.; Haase, D.; et al. TET2 mutations in acute myeloid leukemia (AML): Results from a comprehensive genetic and clinical analysis of the AML study group. J. Clin. Oncol. Off. J. Am. Soc. Clin. Oncol. 2012, 30, 1350-1357. [CrossRef]

27. Paschka, P.; Schlenk, R.F.; Gaidzik, V.I.; Habdank, M.; Kronke, J.; Bullinger, L.; Spath, D.; Kayser, S.; Zucknick, M.; Gotze, K.; et al. IDH1 and IDH2 mutations are frequent genetic alterations in acute myeloid leukemia and confer adverse prognosis in cytogenetically normal acute myeloid leukemia with NPM1 mutation without FLT3 internal tandem duplication. J. Clin. Oncol. Off. J. Am. Soc. Clin. Oncol. 2010, 28, 3636-3643. [CrossRef]

28. Ok, C.Y.; Loghavi, S.; Sui, D.; Wei, P.; Kanagal-Shamanna, R.; Yin, C.C.; Zuo, Z.; Routbort, M.J.; Tang, G.; Tang, Z.; et al. Persistent IDH1/2 mutations in remission can predict relapse in patients with acute myeloid leukemia. Haematologica 2019, 104, 305-311. [CrossRef]

29. Nassereddine, S.; Lap, C.J.; Haroun, F.; Tabbara, I. The role of mutant IDH1 and IDH2 inhibitors in the treatment of acute myeloid leukemia. Ann. Hematol. 2017, 96, 1983-1991. [CrossRef]

30. Ye, D.; Xiong, Y.; Guan, K.L. The mechanisms of IDH mutations in tumorigenesis. Cell Res. 2012, 22, 1102-1104. [CrossRef]

31. Cohen, A.L.; Holmen, S.L.; Colman, H. IDH1 and IDH2 mutations in gliomas. Curr. Neurol. Neurosci. Rep. 2013, 13, 345. [CrossRef] [PubMed]

32. Xie, S.; Wang, Z.; Okano, M.; Nogami, M.; Li, Y.; He, W.W.; Okumura, K.; Li, E. Cloning, expression and chromosome locations of the human DNMT3 gene family. Gene 1999, 236, 87-95. [CrossRef]

33. Okano, M.; Xie, S.; Li, E. Cloning and characterization of a family of novel mammalian DNA (cytosine-5) methyltransferases. Nat. Genet. 1998, 19, 219-220. [CrossRef]

34. Yuan, X.Q.; Chen, P.; Du, Y.X.; Zhu, K.W.; Zhang, D.Y.; Yan, H.; Liu, H.; Liu, Y.L.; Cao, S.; Zhou, G.; et al. Influence of DNMT3A R882 mutations on AML prognosis determined by the allele ratio in Chinese patients. J. Transl. Med. 2019, 17, 220. [CrossRef]

35. Papaemmanuil, E.; Gerstung, M.; Malcovati, L.; Tauro, S.; Gundem, G.; Van Loo, P.; Yoon, C.J.; Ellis, P.; Wedge, D.C.; Pellagatti, A.; et al. Clinical and biological implications of driver mutations in myelodysplastic syndromes. Blood 2013, 122, 3616-3627, quiz 3699. [CrossRef] [PubMed]

36. Ley, T.J.; Ding, L.; Walter, M.J.; McLellan, M.D.; Lamprecht, T.; Larson, D.E.; Kandoth, C.; Payton, J.E.; Baty, J.; Welch, J.; et al. DNMT3A mutations in acute myeloid leukemia. N. Engl. J. Med. 2010, 363, 2424-2433. [CrossRef] [PubMed]

37. Yang, L.; Rau, R.; Goodell, M.A. DNMT3A in haematological malignancies. Nat. Rev. Cancer 2015, 15, 152-165. [CrossRef] [PubMed]

38. Roller, A.; Grossmann, V.; Bacher, U.; Poetzinger, F.; Weissmann, S.; Nadarajah, N.; Boeck, L.; Kern, W.; Haferlach, C.; Schnittger, S.; et al. Landmark analysis of DNMT3A mutations in hematological malignancies. Leukemia 2013, 27, 1573-1578. [CrossRef]

39. Gale, R.E.; Lamb, K.; Allen, C.; El-Sharkawi, D.; Stowe, C.; Jenkinson, S.; Tinsley, S.; Dickson, G.; Burnett, A.K.; Hills, R.K.; et al. Simpson's Paradox and the Impact of Different DNMT3A Mutations on Outcome in Younger Adults With Acute Myeloid Leukemia. J. Clin. Oncol. Off. J. Am. Soc. Clin. Oncol. 2015, 33, $2072-2083$. [CrossRef]

40. Gaidzik, V.I.; Schlenk, R.F.; Paschka, P.; Stolzle, A.; Spath, D.; Kuendgen, A.; von Lilienfeld-Toal, M.; Brugger, W.; Derigs, H.G.; Kremers, S.; et al. Clinical impact of DNMT3A mutations in younger adult patients with acute myeloid leukemia: Results of the AML Study Group (AMLSG). Blood 2013, 121, 4769-4777. [CrossRef]

41. Russler-Germain, D.A.; Spencer, D.H.; Young, M.A.; Lamprecht, T.L.; Miller, C.A.; Fulton, R.; Meyer, M.R.; Erdmann-Gilmore, P.; Townsend, R.R.; Wilson, R.K.; et al. The R882H DNMT3A mutation associated with AML dominantly inhibits wild-type DNMT3A by blocking its ability to form active tetramers. Cancer Cell 2014, 25, 442-454. [CrossRef] [PubMed]

42. Kim, S.J.; Zhao, H.; Hardikar, S.; Singh, A.K.; Goodell, M.A.; Chen, T. A DNMT3A mutation common in AML exhibits dominant-negative effects in murine ES cells. Blood 2013, 122, 4086-4089. [CrossRef] [PubMed]

43. Holz-Schietinger, C.; Matje, D.M.; Reich, N.O. Mutations in DNA methyltransferase (DNMT3A) observed in acute myeloid leukemia patients disrupt processive methylation. J. Biol. Chem. 2012, 287, 30941-30951. [CrossRef] [PubMed] 
44. Yang, L.; Rodriguez, B.; Mayle, A.; Park, H.J.; Lin, X.; Luo, M.; Jeong, M.; Curry, C.V.; Kim, S.B.; Ruau, D.; et al. DNMT3A Loss Drives Enhancer Hypomethylation in FLT3-ITD-Associated Leukemias. Cancer Cell 2016, 30, 363-365. [CrossRef]

45. Meyer, S.E.; Qin, T.; Muench, D.E.; Masuda, K.; Venkatasubramanian, M.; Orr, E.; Suarez, L.; Gore, S.D.; Delwel, R.; Paietta, E.; et al. DNMT3A Haploinsufficiency Transforms FLT3ITD Myeloproliferative Disease into a Rapid, Spontaneous, and Fully Penetrant Acute Myeloid Leukemia. Cancer Discov. 2016, 6, 501-515. [CrossRef]

46. Qu, Y.; Lennartsson, A.; Gaidzik, V.I.; Deneberg, S.; Karimi, M.; Bengtzen, S.; Hoglund, M.; Bullinger, L.; Dohner, K.; Lehmann, S. Differential methylation in CN-AML preferentially targets non-CGI regions and is dictated by DNMT3A mutational status and associated with predominant hypomethylation of HOX genes. Epigenetics 2014, 9, 1108-1119. [CrossRef]

47. Fried, I.; Bodner, C.; Pichler, M.M.; Lind, K.; Beham-Schmid, C.; Quehenberger, F.; Sperr, W.R.; Linkesch, W.; Sill, H.; Wolfler, A. Frequency, onset and clinical impact of somatic DNMT3A mutations in therapy-related and secondary acute myeloid leukemia. Haematologica 2012, 97, 246-250. [CrossRef]

48. Thol, F.; Damm, F.; Ludeking, A.; Winschel, C.; Wagner, K.; Morgan, M.; Yun, H.; Gohring, G.; Schlegelberger, B.; Hoelzer, D.; et al. Incidence and prognostic influence of DNMT3A mutations in acute myeloid leukemia. J. Clin. Oncol. Off. J. Am. Soc. Clin. Oncol. 2011, 29, 2889-2896. [CrossRef]

49. Marcucci, G.; Metzeler, K.H.; Schwind, S.; Becker, H.; Maharry, K.; Mrozek, K.; Radmacher, M.D.; Kohlschmidt, J.; Nicolet, D.; Whitman, S.P.; et al. Age-related prognostic impact of different types of DNMT3A mutations in adults with primary cytogenetically normal acute myeloid leukemia. J. Clin. Oncol. Off. J. Am. Soc. Clin. Oncol. 2012, 30, 742-750. [CrossRef]

50. Corces-Zimmerman, M.R.; Hong, W.J.; Weissman, I.L.; Medeiros, B.C.; Majeti, R. Preleukemic mutations in human acute myeloid leukemia affect epigenetic regulators and persist in remission. Proc. Natl. Acad. Sci. USA 2014, 111, 2548-2553. [CrossRef]

51. Ploen, G.G.; Nederby, L.; Guldberg, P.; Hansen, M.; Ebbesen, L.H.; Jensen, U.B.; Hokland, P.; Aggerholm, A. Persistence of DNMT3A mutations at long-term remission in adult patients with AML. Br. J. Haematol. 2014, 167, 478-486. [CrossRef] [PubMed]

52. Brunetti, L.; Gundry, M.C.; Goodell, M.A. DNMT3A in Leukemia. Cold Spring Harb. Perspect. Med. $2017,7$. [CrossRef] [PubMed]

53. Feng, Y.; Li, X.; Cassady, K.; Zou, Z.; Zhang, X. TET2 Function in Hematopoietic Malignancies, Immune Regulation, and DNA Repair. Front. Oncol. 2019, 9, 210. [CrossRef] [PubMed]

54. Solary, E.; Bernard, O.A.; Tefferi, A.; Fuks, F.; Vainchenker, W. The Ten-Eleven Translocation-2 (TET2) gene in hematopoiesis and hematopoietic diseases. Leukemia 2014, 28, 485-496. [CrossRef]

55. Delhommeau, F.; Dupont, S.; Della Valle, V.; James, C.; Trannoy, S.; Masse, A.; Kosmider, O.; Le Couedic, J.P.; Robert, F.; Alberdi, A.; et al. Mutation in TET2 in myeloid cancers. N. Engl. J. Med. 2009, 360, $2289-2301$. [CrossRef]

56. Moran-Crusio, K.; Reavie, L.; Shih, A.; Abdel-Wahab, O.; Ndiaye-Lobry, D.; Lobry, C.; Figueroa, M.E.; Vasanthakumar, A.; Patel, J.; Zhao, X.; et al. Tet2 loss leads to increased hematopoietic stem cell self-renewal and myeloid transformation. Cancer Cell 2011, 20, 11-24. [CrossRef]

57. Jankowska, A.M.; Szpurka, H.; Tiu, R.V.; Makishima, H.; Afable, M.; Huh, J.; O’Keefe, C.L.; Ganetzky, R.; McDevitt, M.A.; Maciejewski, J.P. Loss of heterozygosity 4q24 and TET2 mutations associated with myelodysplastic/myeloproliferative neoplasms. Blood 2009, 113, 6403-6410. [CrossRef]

58. Ahn, J.S.; Kim, H.J.; Kim, Y.K.; Jung, S.H.; Yang, D.H.; Lee, J.J.; Lee, I.K.; Kim, N.Y.; Minden, M.D.; Jung, C.W.; et al. Adverse prognostic effect of homozygous TET2 mutation on the relapse risk of acute myeloid leukemia in patients of normal karyotype. Haematologica 2015, 100, e351-e353. [CrossRef]

59. Weissmann, S.; Alpermann, T.; Grossmann, V.; Kowarsch, A.; Nadarajah, N.; Eder, C.; Dicker, F.; Fasan, A.; Haferlach, C.; Haferlach, T.; et al. Landscape of TET2 mutations in acute myeloid leukemia. Leukemia 2012, 26, 934-942. [CrossRef]

60. Cimmino, L.; Abdel-Wahab, O.; Levine, R.L.; Aifantis, I. TET family proteins and their role in stem cell differentiation and transformation. Cell Stem Cell 2011, 9, 193-204. [CrossRef]

61. Yang, L.; Han, Y.; Suarez Saiz, F.; Minden, M.D. A tumor suppressor and oncogene: The WT1 story. Leukemia 2007, 21, 868-876. [CrossRef] [PubMed] 
62. Rampal, R.; Figueroa, M.E. Wilms tumor 1 mutations in the pathogenesis of acute myeloid leukemia. Haematologica 2016, 101, 672-679. [CrossRef] [PubMed]

63. Morris, J.F.; Madden, S.L.; Tournay, O.E.; Cook, D.M.; Sukhatme, V.P.; Rauscher, F.J., 3rd. Characterization of the zinc finger protein encoded by the WT1 Wilms' tumor locus. Oncogene 1991, 6, 2339-2348. [PubMed]

64. Ariyaratana, S.; Loeb, D.M. The role of the Wilms tumour gene (WT1) in normal and malignant haematopoiesis. Expert Rev. Mol. Med. 2007, 9, 1-17. [CrossRef] [PubMed]

65. Weiss, T.C.; Romaniuk, P.J. Contribution of individual amino acids to the RNA binding activity of the Wilms' tumor suppressor protein WT1. Biochemistry 2009, 48, 148-155. [CrossRef] [PubMed]

66. Haber, D.A.; Sohn, R.L.; Buckler, A.J.; Pelletier, J.; Call, K.M.; Housman, D.E. Alternative splicing and genomic structure of the Wilms tumor gene WT1. Proc. Natl. Acad. Sci. USA 1991, 88, 9618-9622. [CrossRef] [PubMed]

67. Luna, I.; Such, E.; Cervera, J.; Barragan, E.; Ibanez, M.; Gomez-Segui, I.; Lopez-Pavia, M.; Llop, M.; Fuster, O.; Dolz, S.; et al. WT1 isoform expression pattern in acute myeloid leukemia. Leuk. Res. 2013, 37, 1744-1749. [CrossRef]

68. Ellisen, L.W.; Carlesso, N.; Cheng, T.; Scadden, D.T.; Haber, D.A. The Wilms tumor suppressor WT1 directs stage-specific quiescence and differentiation of human hematopoietic progenitor cells. EMBO J. 2001, 20, 1897-1909. [CrossRef]

69. Baird, P.N.; Simmons, P.J. Expression of the Wilms' tumor gene (WT1) in normal hemopoiesis. Exp. Hematol. 1997, 25, 312-320.

70. Miwa, H.; Beran, M.; Saunders, G.F. Expression of the Wilms' tumor gene (WT1) in human leukemias. Leukemia 1992, 6, 405-409.

71. Cilloni, D.; Renneville, A.; Hermitte, F.; Hills, R.K.; Daly, S.; Jovanovic, J.V.; Gottardi, E.; Fava, M.; Schnittger, S.; Weiss, T.; et al. Real-time quantitative polymerase chain reaction detection of minimal residual disease by standardized WT1 assay to enhance risk stratification in acute myeloid leukemia: A European LeukemiaNet study. J. Clin. Oncol. Off. J. Am. Soc. Clin. Oncol. 2009, 27, 5195-5201. [CrossRef] [PubMed]

72. Hou, H.A.; Huang, T.C.; Lin, L.I.; Liu, C.Y.; Chen, C.Y.; Chou, W.C.; Tang, J.L.; Tseng, M.H.; Huang, C.F.; Chiang, Y.C.; et al. WT1 mutation in 470 adult patients with acute myeloid leukemia: Stability during disease evolution and implication of its incorporation into a survival scoring system. Blood 2010, 115, 5222-5231. [CrossRef] [PubMed]

73. Abbas, S.; Erpelinck-Verschueren, C.A.; Goudswaard, C.S.; Lowenberg, B.; Valk, P.J. Mutant Wilms' tumor 1 (WT1) mRNA with premature termination codons in acute myeloid leukemia (AML) is sensitive to nonsense-mediated RNA decay (NMD). Leukemia 2010, 24, 660-663. [CrossRef] [PubMed]

74. Gaidzik, V.I.; Schlenk, R.F.; Moschny, S.; Becker, A.; Bullinger, L.; Corbacioglu, A.; Krauter, J.; Schlegelberger, B.; Ganser, A.; Dohner, H.; et al. Prognostic impact of WT1 mutations in cytogenetically normal acute myeloid leukemia: A study of the German-Austrian AML Study Group. Blood 2009, 113, 4505-4511. [CrossRef]

75. Fernandez, H.F.; Sun, Z.; Yao, X.; Litzow, M.R.; Luger, S.M.; Paietta, E.M.; Racevskis, J.; Dewald, G.W.; Ketterling, R.P.; Bennett, J.M.; et al. Anthracycline dose intensification in acute myeloid leukemia. N. Engl. J. Med. 2009, 361, 1249-1259. [CrossRef]

76. Rampal, R.; Alkalin, A.; Madzo, J.; Vasanthakumar, A.; Pronier, E.; Patel, J.; Li, Y.; Ahn, J.; Abdel-Wahab, O.; Shih, A.; et al. DNA hydroxymethylation profiling reveals that WT1 mutations result in loss of TET2 function in acute myeloid leukemia. Cell Rep. 2014, 9, 1841-1855. [CrossRef]

77. Pronier, E.; Bowman, R.L.; Ahn, J.; Glass, J.; Kandoth, C.; Merlinsky, T.R.; Whitfield, J.T.; Durham, B.H.; Gruet, A.; Hanasoge Somasundara, A.V.; et al. Genetic and epigenetic evolution as a contributor to WT1-mutant leukemogenesis. Blood 2018, 132, 1265-1278. [CrossRef]

78. Aref, S.; Sharawy, S.E.; Sabry, M.; Azmy, E.; Raouf, D.A.; Menshawy, N.E. Wilms tumor 1 gene mutations in patients with cytogenetically normal acute myeloid leukemia. Turk. J. Haematol. Off. J. Turk. Soc. Haematol. 2014, 31, 143-148. [CrossRef]

79. Petiti, J.; Rosso, V.; Lo Iacono, M.; Calabrese, C.; Signorino, E.; Gaidano, V.; Berger, M.; Saglio, G.; Cilloni, D. Prognostic significance of The Wilms' Tumor-1 (WT1) rs16754 polymorphism in acute myeloid leukemia. Leuk. Res. 2018, 67, 6-11. [CrossRef] 
80. Toogeh, G.; Ramzi, M.; Faranoush, M.; Amirizadeh, N.; Haghpanah, S.; Moghadam, M.; Cohan, N. Prevalence and Prognostic Impact of Wilms' Tumor 1 (WT1) Gene, Including SNP rs16754 in Cytogenetically Normal Acute Myeloblastic Leukemia (CN-AML): An Iranian Experience. Clin. Lymphomamyeloma Leuk. 2016, 16, e21-e26. [CrossRef]

81. Fisher, C.L.; Pineault, N.; Brookes, C.; Helgason, C.D.; Ohta, H.; Bodner, C.; Hess, J.L.; Humphries, R.K.; Brock, H.W. Loss-of-function Additional sex combs like 1 mutations disrupt hematopoiesis but do not cause severe myelodysplasia or leukemia. Blood 2010, 115, 38-46. [CrossRef] [PubMed]

82. Fisher, C.L.; Randazzo, F.; Humphries, R.K.; Brock, H.W. Characterization of Asxl1, a murine homolog of Additional sex combs, and analysis of the Asx-like gene family. Gene 2006, 369, 109-118. [CrossRef] [PubMed]

83. Abdel-Wahab, O.; Dey, A. The ASXL-BAP1 axis: New factors in myelopoiesis, cancer and epigenetics. Leukemia 2013, 27, 10-15. [CrossRef] [PubMed]

84. Margueron, R.; Reinberg, D. The Polycomb complex PRC2 and its mark in life. Nature 2011, 469, 343-349. [CrossRef] [PubMed]

85. Abdel-Wahab, O.; Adli, M.; LaFave, L.M.; Gao, J.; Hricik, T.; Shih, A.H.; Pandey, S.; Patel, J.P.; Chung, Y.R.; Koche, R.; et al. ASXL1 mutations promote myeloid transformation through loss of PRC2-mediated gene repression. Cancer Cell 2012, 22, 180-193. [CrossRef] [PubMed]

86. Sanchez, R.; Zhou, M.M. The PHD finger: A versatile epigenome reader. Trends Biochem. Sci. 2011, 36, 364-372. [CrossRef]

87. Inoue, D.; Fujino, T.; Kitamura, T. ASXL1 as a critical regulator of epigenetic marks and therapeutic potential of mutated cells. Oncotarget 2018, 9, 35203-35204. [CrossRef]

88. Alvarez Argote, J.; Dasanu, C.A. ASXL1 mutations in myeloid neoplasms: Pathogenetic considerations, impact on clinical outcomes and survival. Curr. Med. Res. Opin. 2018, 34, 757-763. [CrossRef]

89. Sahtoe, D.D.; van Dijk, W.J.; Ekkebus, R.; Ovaa, H.; Sixma, T.K. BAP1/ASXL1 recruitment and activation for H2A deubiquitination. Nat. Commun. 2016, 7, 10292. [CrossRef]

90. Hsu, Y.C.; Chiu, Y.C.; Lin, C.C.; Kuo, Y.Y.; Hou, H.A.; Tzeng, Y.S.; Kao, C.J.; Chuang, P.H.; Tseng, M.H.; Hsiao, T.H.; et al. The distinct biological implications of Asxl1 mutation and its roles in leukemogenesis revealed by a knock-in mouse model. J. Hematol. Oncol. 2017, 10, 139. [CrossRef]

91. Gelsi-Boyer, V.; Brecqueville, M.; Devillier, R.; Murati, A.; Mozziconacci, M.J.; Birnbaum, D. Mutations in ASXL1 are associated with poor prognosis across the spectrum of malignant myeloid diseases. J. Hematol. Oncol. 2012, 5, 12. [CrossRef] [PubMed]

92. Paschka, P.; Schlenk, R.F.; Gaidzik, V.I.; Herzig, J.K.; Aulitzky, T.; Bullinger, L.; Spath, D.; Teleanu, V.; Kundgen, A.; Kohne, C.H.; et al. ASXL1 mutations in younger adult patients with acute myeloid leukemia: A study by the German-Austrian Acute Myeloid Leukemia Study Group. Haematologica 2015, 100, 324-330. [CrossRef] [PubMed]

93. Lin, Y.; Zheng, Y.; Wang, Z.C.; Wang, S.Y. Prognostic significance of ASXL1 mutations in myelodysplastic syndromes and chronic myelomonocytic leukemia: A meta-analysis. Hematology 2016, 21, 454-461. [CrossRef] [PubMed]

94. Schnittger, S.; Eder, C.; Jeromin, S.; Alpermann, T.; Fasan, A.; Grossmann, V.; Kohlmann, A.; Illig, T.; Klopp, N.; Wichmann, H.E.; et al. ASXL1 exon 12 mutations are frequent in AML with intermediate risk karyotype and are independently associated with an adverse outcome. Leukemia 2013, 27, 82-91. [CrossRef] [PubMed]

95. Kakosaiou, K.; Panitsas, F.; Daraki, A.; Pagoni, M.; Apostolou, P.; Ioannidou, A.; Vlachadami, I.; Marinakis, T.; Giatra, C.; Vasilatou, D.; et al. ASXL1 mutations in AML are associated with specific clinical and cytogenetic characteristics. Leuk. Lymphoma 2018, 59, 2439-2446. [CrossRef]

96. Rocquain, J.; Carbuccia, N.; Trouplin, V.; Raynaud, S.; Murati, A.; Nezri, M.; Tadrist, Z.; Olschwang, S.; Vey, N.; Birnbaum, D.; et al. Combined mutations of ASXL1, CBL, FLT3, IDH1, IDH2, JAK2, KRAS, NPM1, NRAS, RUNX1, TET2 and WT1 genes in myelodysplastic syndromes and acute myeloid leukemias. BMC Cancer 2010, 10, 401. [CrossRef]

97. Carbuccia, N.; Trouplin, V.; Gelsi-Boyer, V.; Murati, A.; Rocquain, J.; Adelaide, J.; Olschwang, S.; Xerri, L.; Vey, N.; Chaffanet, M.; et al. Mutual exclusion of ASXL1 and NPM1 mutations in a series of acute myeloid leukemias. Leukemia 2010, 24, 469-473. [CrossRef] 
98. Yang, H.; Kurtenbach, S.; Guo, Y.; Lohse, I.; Durante, M.A.; Li, J.; Li, Z.; Al-Ali, H.; Li, L.; Chen, Z.; et al. Gain of function of ASXL1 truncating protein in the pathogenesis of myeloid malignancies. Blood 2018, 131, 328-341. [CrossRef]

99. An, Q.; Wright, S.L.; Moorman, A.V.; Parker,H.; Griffiths, M.; Ross, F.M.; Davies, T.; Harrison, C.J.; Strefford, J.C. Heterogeneous breakpoints in patients with acute lymphoblastic leukemia and the $\operatorname{dic}(9 ; 20)(\mathrm{p} 11-13 ; \mathrm{q} 11)$ show recurrent involvement of genes at 20q11.21. Haematologica 2009, 94, 1164-1169. [CrossRef]

100. Eirin-Lopez, J.M.; Frehlick, L.J.; Ausio, J. Long-term evolution and functional diversification in the members of the nucleophosmin/nucleoplasmin family of nuclear chaperones. Genetics 2006, 173, 1835-1850. [CrossRef]

101. Falini, B.; Mecucci, C.; Tiacci, E.; Alcalay, M.; Rosati, R.; Pasqualucci, L.; La Starza, R.; Diverio, D.; Colombo, E.; Santucci, A.; et al. Cytoplasmic nucleophosmin in acute myelogenous leukemia with a normal karyotype. N. Engl. J. Med. 2005, 352, 254-266. [CrossRef] [PubMed]

102. Okuda, M. The role of nucleophosmin in centrosome duplication. Oncogene 2002, 21, 6170-6174. [CrossRef] [PubMed]

103. Gjerset, R.A. DNA damage, p14ARF, nucleophosmin (NPM/B23), and cancer. J. Mol. Histol. 2006, 37, $239-251$. [CrossRef] [PubMed]

104. Colombo, E.; Marine, J.C.; Danovi, D.; Falini, B.; Pelicci, P.G. Nucleophosmin regulates the stability and transcriptional activity of p53. Nat. Cell Biol. 2002, 4, 529-533. [CrossRef]

105. Ye, M.; Zhang, H.; Amabile, G.; Yang, H.; Staber, P.B.; Zhang, P.; Levantini, E.; Alberich-Jorda, M.; Zhang, J.; Kawasaki, A.; et al. C/EBPa controls acquisition and maintenance of adult haematopoietic stem cell quiescence. Nat. Cell Biol. 2013, 15, 385-394. [CrossRef]

106. Falini, B.; Martelli, M.P.; Bolli, N.; Sportoletti, P.; Liso, A.; Tiacci, E.; Haferlach, T. Acute myeloid leukemia with mutated nucleophosmin (NPM1): Is it a distinct entity? Blood 2011, 117, 1109-1120. [CrossRef]

107. Heath, E.M.; Chan, S.M.; Minden, M.D.; Murphy, T.; Shlush, L.I.; Schimmer, A.D. Biological and clinical consequences of NPM1 mutations in AML. Leukemia 2017, 31, 798-807. [CrossRef]

108. Kunchala, P.; Kuravi, S.; Jensen, R.; McGuirk, J.; Balusu, R. When the good go bad: Mutant NPM1 in acute myeloid leukemia. Blood Rev. 2018, 32, 167-183. [CrossRef]

109. Vassiliou, G.S.; Cooper, J.L.; Rad, R.; Li, J.; Rice, S.; Uren, A.; Rad, L.; Ellis, P.; Andrews, R.; Banerjee, R.; et al. Mutant nucleophosmin and cooperating pathways drive leukemia initiation and progression in mice. Nat. Genet. 2011, 43, 470-475. [CrossRef]

110. Falini, B.; Nicoletti, I.; Bolli, N.; Martelli, M.P.; Liso, A.; Gorello, P.; Mandelli, F.; Mecucci, C.; Martelli, M.F. Translocations and mutations involving the nucleophosmin (NPM1) gene in lymphomas and leukemias. Haematologica 2007, 92, 519-532. [CrossRef]

111. Schnittger, S.; Schoch, C.; Kern, W.; Mecucci, C.; Tschulik, C.; Martelli, M.F.; Haferlach, T.; Hiddemann, W.; Falini, B. Nucleophosmin gene mutations are predictors of favorable prognosis in acute myelogenous leukemia with a normal karyotype. Blood 2005, 106, 3733-3739. [CrossRef]

112. Liu, Y.; He, P.; Liu, F.; Shi, L.; Zhu, H.; Zhao, J.; Wang, Y.; Cheng, X.; Zhang, M. Prognostic significance of NPM1 mutations in acute myeloid leukemia: A meta-analysis. Mol. Clin. Oncol. 2014, 2, 275-281. [CrossRef] [PubMed]

113. Pratcorona, M.; Brunet, S.; Nomdedeu, J.; Ribera, J.M.; Tormo, M.; Duarte, R.; Escoda, L.; Guardia, R.; Queipo de Llano, M.P.; Salamero, O.; et al. Favorable outcome of patients with acute myeloid leukemia harboring a low-allelic burden FLT3-ITD mutation and concomitant NPM1 mutation: Relevance to post-remission therapy. Blood 2013, 121, 2734-2738. [CrossRef]

114. Forghieri, F.; Comoli, P.; Marasca, R.; Potenza, L.; Luppi, M. Minimal/Measurable Residual Disease Monitoring in NPM1-Mutated Acute Myeloid Leukemia: A Clinical Viewpoint and Perspectives. Int. J. Mol. Sci. 2018, 19, 3492. [CrossRef] [PubMed]

115. Mosna, F.; Capelli, D.; Gottardi, M. Minimal Residual Disease in Acute Myeloid Leukemia: Still a Work in Progress? J. Clin. Med. 2017, 6, 57. [CrossRef] [PubMed]

116. Boddu, P.; Kantarjian, H.; Borthakur, G.; Kadia, T.; Daver, N.; Pierce, S.; Andreeff, M.; Ravandi, F.; Cortes, J.; Kornblau, S.M. Co-occurrence of FLT3-TKD and NPM1 mutations defines a highly favorable prognostic AML group. Blood Adv. 2017, 1, 1546-1550. [CrossRef]

117. Rose, D.; Haferlach, T.; Schnittger, S.; Perglerova, K.; Kern, W.; Haferlach, C. Subtype-specific patterns of molecular mutations in acute myeloid leukemia. Leukemia 2017, 31, 11-17. [CrossRef] 
118. Morris, S.W.; Kirstein, M.N.; Valentine, M.B.; Dittmer, K.G.; Shapiro, D.N.; Saltman, D.L.; Look, A.T. Fusion of a kinase gene, ALK, to a nucleolar protein gene, NPM, in non-Hodgkin's lymphoma. Science 1994, 263, 1281-1284. [CrossRef]

119. Redner, R.L.; Rush, E.A.; Faas, S.; Rudert, W.A.; Corey, S.J. The t(5;17) variant of acute promyelocytic leukemia expresses a nucleophosmin-retinoic acid receptor fusion. Blood 1996, 87, 882-886. [CrossRef]

120. Birkenmeier, E.H.; Gwynn, B.; Howard, S.; Jerry, J.; Gordon, J.I.; Landschulz, W.H.; McKnight, S.L. Tissue-specific expression, developmental regulation, and genetic mapping of the gene encoding CCAAT/enhancer binding protein. Genes Dev. 1989, 3, 1146-1156. [CrossRef]

121. Pundhir, S.; Bratt Lauridsen, F.K.; Schuster, M.B.; Jakobsen, J.S.; Ge, Y.; Schoof, E.M.; Rapin, N.; Waage, J.; Hasemann, M.S.; Porse, B.T. Enhancer and Transcription Factor Dynamics during Myeloid Differentiation Reveal an Early Differentiation Block in Cebpa null Progenitors. Cell Rep. 2018, 23, 2744-2757. [CrossRef] [PubMed]

122. Reddy, V.A.; Iwama, A.; Iotzova, G.; Schulz, M.; Elsasser, A.; Vangala, R.K.; Tenen, D.G.; Hiddemann, W.; Behre, G. Granulocyte inducer C/EBPalpha inactivates the myeloid master regulator PU.1: Possible role in lineage commitment decisions. Blood 2002, 100, 483-490. [CrossRef] [PubMed]

123. Heuston, E.F. The potential of a single enhancer. Blood 2016, 127, 2943-2944. [CrossRef] [PubMed]

124. Porse, B.T.; Bryder, D.; Theilgaard-Monch, K.; Hasemann, M.S.; Anderson, K.; Damgaard, I.; Jacobsen, S.E.; Nerlov, C. Loss of C/EBP alpha cell cycle control increases myeloid progenitor proliferation and transforms the neutrophil granulocyte lineage. J. Exp. Med. 2005, 202, 85-96. [CrossRef]

125. Pabst, T.; Mueller, B.U.; Zhang, P.; Radomska, H.S.; Narravula, S.; Schnittger, S.; Behre, G.; Hiddemann, W.; Tenen, D.G. Dominant-negative mutations of CEBPA, encoding CCAAT/enhancer binding protein-alpha (C/EBPalpha), in acute myeloid leukemia. Nat. Genet. 2001, 27, 263-270. [CrossRef]

126. Leroy, H.; Roumier, C.; Huyghe, P.; Biggio, V.; Fenaux, P.; Preudhomme, C. CEBPA point mutations in hematological malignancies. Leukemia 2005, 19, 329-334. [CrossRef]

127. Pabst, T.; Mueller, B.U. Complexity of CEBPA dysregulation in human acute myeloid leukemia. Clin. Cancer Res. Off. J. Am. Assoc. Cancer Res. 2009, 15, 5303-5307. [CrossRef]

128. Dufour, A.; Schneider, F.; Metzeler, K.H.; Hoster, E.; Schneider, S.; Zellmeier, E.; Benthaus, T.; Sauerland, M.C.; Berdel, W.E.; Buchner, T.; et al. Acute myeloid leukemia with biallelic CEBPA gene mutations and normal karyotype represents a distinct genetic entity associated with a favorable clinical outcome. J. Clin. Oncol. Off. J. Am. Soc. Clin. Oncol. 2010, 28, 570-577. [CrossRef]

129. Mannelli, F.; Ponziani, V.; Bencini, S.; Bonetti, M.I.; Benelli, M.; Cutini, I.; Gianfaldoni, G.; Scappini, B.; Pancani, F.; Piccini, M.; et al. CEBPA-double-mutated acute myeloid leukemia displays a unique phenotypic profile: A reliable screening method and insight into biological features. Haematologica 2017, 102, 529-540. [CrossRef]

130. Su, L.; Tan, Y.; Lin, H.; Liu, X.; Yu, L.; Yang, Y.; Liu, S.; Bai, O.; Yang, Y.; Jin, F.; et al. Mutational spectrum of acute myeloid leukemia patients with double CEBPA mutations based on next-generation sequencing and its prognostic significance. Oncotarget 2018, 9, 24970-24979. [CrossRef]

131. Grossmann, V.; Haferlach, C.; Nadarajah, N.; Fasan, A.; Weissmann, S.; Roller, A.; Eder, C.; Stopp, E.; Kern, W.; Haferlach, T.; et al. CEBPA double-mutated acute myeloid leukaemia harbours concomitant molecular mutations in $76.8 \%$ of cases with TET2 and GATA2 alterations impacting prognosis. Br. J. Haematol. 2013, 161, 649-658. [CrossRef] [PubMed]

132. Green, C.L.; Koo, K.K.; Hills, R.K.; Burnett, A.K.; Linch, D.C.; Gale, R.E. Prognostic significance of CEBPA mutations in a large cohort of younger adult patients with acute myeloid leukemia: Impact of double CEBPA mutations and the interaction with FLT3 and NPM1 mutations. J. Clin. Oncol. Off. J. Am. Soc. Clin. Oncol. 2010, 28, 2739-2747. [CrossRef] [PubMed]

133. Fasan, A.; Haferlach, C.; Alpermann, T.; Jeromin, S.; Grossmann, V.; Eder, C.; Weissmann, S.; Dicker, F.; Kohlmann, A.; Schindela, S.; et al. The role of different genetic subtypes of CEBPA mutated AML. Leukemia 2014, 28, 794-803. [CrossRef] [PubMed]

134. Zhang, Y.; Wang, F.; Chen, X.; Zhang, Y.; Wang, M.; Liu, H.; Cao, P.; Ma, X.; Wang, T.; Zhang, J.; et al. CSF3R Mutations are frequently associated with abnormalities of RUNX1, CBFB, CEBPA, and NPM1 genes in acute myeloid leukemia. Cancer 2018, 124, 3329-3338. [CrossRef] 
135. Lavallee, V.P.; Krosl, J.; Lemieux, S.; Boucher, G.; Gendron, P.; Pabst, C.; Boivin, I.; Marinier, A.; Guidos, C.J.; Meloche, $\mathrm{S}$; et al. Chemo-genomic interrogation of CEBPA mutated AML reveals recurrent CSF3R mutations and subgroup sensitivity to JAK inhibitors. Blood 2016, 127, 3054-3061. [CrossRef]

136. Su, L.; Gao, S.; Tan, Y.; Lin, H.; Liu, X.; Liu, S.; Yang, Y.; Sun, J.; Li, W. CSF3R mutations were associated with an unfavorable prognosis in patients with acute myeloid leukemia with CEBPA double mutations. Ann. Hematol. 2019, 98, 1641-1646. [CrossRef]

137. Braun, T.P.; Okhovat, M.; Coblentz, C.; Carratt, S.A.; Foley, A.; Schonrock, Z.; Smith, B.M.; Nevonen, K.; Davis, B.; Garcia, B.; et al. Myeloid lineage enhancers drive oncogene synergy in CEBPA/CSF3R mutant acute myeloid leukemia. Nat. Commun. 2019, 10, 5455. [CrossRef]

138. Lane, D.P. Cancer. p53, guardian of the genome. Nature 1992, 358, 15-16. [CrossRef]

139. Lee, S.; Cavallo, L.; Griffith, J. Human p53 binds Holliday junctions strongly and facilitates their cleavage. J. Biol. Chem. 1997, 272, 7532-7539. [CrossRef]

140. Wong, T.N.; Ramsingh, G.; Young, A.L.; Miller, C.A.; Touma, W.; Welch, J.S.; Lamprecht, T.L.; Shen, D.; Hundal, J.; Fulton, R.S.; et al. Role of TP53 mutations in the origin and evolution of therapy-related acute myeloid leukaemia. Nature 2015, 518, 552-555. [CrossRef]

141. Seifert, H.; Mohr, B.; Thiede, C.; Oelschlagel, U.; Schakel, U.; Illmer, T.; Soucek, S.; Ehninger, G.; Schaich, M.; Study Alliance, L. The prognostic impact of 17p (p53) deletion in 2272 adults with acute myeloid leukemia. Leukemia 2009, 23, 656-663. [CrossRef] [PubMed]

142. Kadia, T.M.; Jain, P.; Ravandi, F.; Garcia-Manero, G.; Andreef, M.; Takahashi, K.; Borthakur, G.; Jabbour, E.; Konopleva, M.; Daver, N.G.; et al. TP53 mutations in newly diagnosed acute myeloid leukemia: Clinicomolecular characteristics, response to therapy, and outcomes. Cancer 2016, 122, 3484-3491. [CrossRef] [PubMed]

143. Prochazka, K.T.; Pregartner, G.; Rucker, F.G.; Heitzer, E.; Pabst, G.; Wolfler, A.; Zebisch, A.; Berghold, A.; Dohner, K.; Sill, H. Clinical implications of subclonal TP53 mutations in acute myeloid leukemia. Haematologica 2019, 104, 516-523. [CrossRef] [PubMed]

144. Rucker, F.G.; Schlenk, R.F.; Bullinger, L.; Kayser, S.; Teleanu, V.; Kett, H.; Habdank, M.; Kugler, C.M.; Holzmann, K.; Gaidzik, V.I.; et al. TP53 alterations in acute myeloid leukemia with complex karyotype correlate with specific copy number alterations, monosomal karyotype, and dismal outcome. Blood 2012, 119, 2114-2121. [CrossRef]

145. Haferlach, C.; Dicker, F.; Herholz, H.; Schnittger, S.; Kern, W.; Haferlach, T. Mutations of the TP53 gene in acute myeloid leukemia are strongly associated with a complex aberrant karyotype. Leukemia 2008, 22, 1539-1541. [CrossRef]

146. Roake, C.M.; Artandi, S.E. Control of Cellular Aging, Tissue Function, and Cancer by p53 Downstream of Telomeres. Cold Spring Harb. Perspect. Med. 2017, 7. [CrossRef]

147. Bouaoun, L.; Sonkin, D.; Ardin, M.; Hollstein, M.; Byrnes, G.; Zavadil, J.; Olivier, M. TP53 Variations in Human Cancers: New Lessons from the IARC TP53 Database and Genomics Data. Hum. Mutat. 2016, 37, 865-876. [CrossRef]

148. Christiansen, D.H.; Andersen, M.K.; Pedersen-Bjergaard, J. Mutations with loss of heterozygosity of p53 are common in therapy-related myelodysplasia and acute myeloid leukemia after exposure to alkylating agents and significantly associated with deletion or loss of 5q, a complex karyotype, and a poor prognosis. J. Clin. Oncol. Off. J. Am. Soc. Clin. Oncol. 2001, 19, 1405-1413. [CrossRef]

149. Prokocimer, M.; Molchadsky, A.; Rotter, V. Dysfunctional diversity of p53 proteins in adult acute myeloid leukemia: Projections on diagnostic workup and therapy. Blood 2017, 130, 699-712. [CrossRef]

150. Carvajal, L.A.; Neriah, D.B.; Senecal, A.; Benard, L.; Thiruthuvanathan, V.; Yatsenko, T.; Narayanagari, S.R.; Wheat, J.C.; Todorova, T.I.; Mitchell, K.; et al. Dual inhibition of MDMX and MDM2 as a therapeutic strategy in leukemia. Sci. Transl. Med. 2018, 10. [CrossRef]

151. Sasca, D.; Hahnel, P.S.; Szybinski, J.; Khawaja, K.; Kriege, O.; Pante, S.V.; Bullinger, L.; Strand, S.; Strand, D.; Theobald, M.; et al. SIRT1 prevents genotoxic stress-induced p53 activation in acute myeloid leukemia. Blood 2014, 124, 121-133. [CrossRef] [PubMed]

152. Le, M.T.; Teh, C.; Shyh-Chang, N.; Xie, H.; Zhou, B.; Korzh, V.; Lodish, H.F.; Lim, B. MicroRNA-125b is a novel negative regulator of p53. Genes Dev. 2009, 23, 862-876. [CrossRef] [PubMed]

153. Chen, D.; Yoon, J.B.; Gu, W. Reactivating the ARF-p53 axis in AML cells by targeting ULF. Cell Cycle 2010, 9 , 2946-2951. [CrossRef] [PubMed] 
154. Ramsey, H.E.; Fischer, M.A.; Lee, T.; Gorska, A.E.; Arrate, M.P.; Fuller, L.; Boyd, K.L.; Strickland, S.A.; Sensintaffar, J.; Hogdal, L.J.; et al. A Novel MCL1 Inhibitor Combined with Venetoclax Rescues Venetoclax-Resistant Acute Myelogenous Leukemia. Cancer Discov. 2018, 8, 1566-1581. [CrossRef] [PubMed]

155. Di Croce, L.; Helin, K. Transcriptional regulation by Polycomb group proteins. Nat. Struct. Mol. Biol. 2013, 20, 1147-1155. [CrossRef] [PubMed]

156. Lund, K.; Adams, P.D.; Copland, M. EZH2 in normal and malignant hematopoiesis. Leukemia 2014, 28 , 44-49. [CrossRef]

157. Maes, T.; Mascaro, C.; Tirapu, I.; Estiarte, A.; Ciceri, F.; Lunardi, S.; Guibourt, N.; Perdones, A.; Lufino, M.M.P.; Somervaille, T.C.P.; et al. ORY-1001, a Potent and Selective Covalent KDM1A Inhibitor, for the Treatment of Acute Leukemia. Cancer Cell 2018, 33, 495-511 e412. [CrossRef]

158. Visconte, V.; O Nakashima, M.; J Rogers, H. Mutations in Splicing Factor Genes in Myeloid Malignancies: Significance and Impact on Clinical Features. Cancers 2019, 11, 1844. [CrossRef]

159. Papaemmanuil, E.; Cazzola, M.; Boultwood, J.; Malcovati, L.; Vyas, P.; Bowen, D.; Pellagatti, A.; Wainscoat, J.S.; Hellstrom-Lindberg, E.; Gambacorti-Passerini, C.; et al. Somatic SF3B1 mutation in myelodysplasia with ring sideroblasts. N. Engl. J. Med. 2011, 365, 1384-1395. [CrossRef]

160. Yoshida, K.; Sanada, M.; Shiraishi, Y.; Nowak, D.; Nagata, Y.; Yamamoto, R.; Sato, Y.; Sato-Otsubo, A.; Kon, A.; Nagasaki, M.; et al. Frequent pathway mutations of splicing machinery in myelodysplasia. Nature 2011, 478, 64-69. [CrossRef]

161. Hou, H.A.; Liu, C.Y.; Kuo, Y.Y.; Chou, W.C.; Tsai, C.H.; Lin, C.C.; Lin, L.I.; Tseng, M.H.; Chiang, Y.C.; Liu, M.C.; et al. Splicing factor mutations predict poor prognosis in patients with de novo acute myeloid leukemia. Oncotarget 2016, 7, 9084-9101. [CrossRef] [PubMed]

162. Wang, H.; Peng, R.; Wang, J.; Qin, Z.; Xue, L. Circulating microRNAs as potential cancer biomarkers: The advantage and disadvantage. Clin. Epigenetics 2018, 10, 59. [CrossRef]

163. Wallace, J.A.; O'Connell, R.M. MicroRNAs and acute myeloid leukemia: Therapeutic implications and emerging concepts. Blood 2017, 130, 1290-1301. [CrossRef] [PubMed]

164. Grasedieck, S.; Sorrentino, A.; Langer, C.; Buske, C.; Dohner, H.; Mertens, D.; Kuchenbauer, F. Circulating microRNAs in hematological diseases: Principles, challenges, and perspectives. Blood 2013, 121, 4977-4984. [CrossRef] [PubMed]

165. Xiao, Y.; Su, C.; Deng, T. miR-223 decreases cell proliferation and enhances cell apoptosis in acute myeloid leukemia via targeting FBXW7. Oncol. Lett. 2016, 12, 3531-3536. [CrossRef]

166. Zhang, L.; Liao, Y.; Tang, L. MicroRNA-34 family: A potential tumor suppressor and therapeutic candidate in cancer. J. Exp. Clin. Cancer Res. Cr 2019, 38, 53. [CrossRef]

167. Shen, C.; Chen, M.T.; Zhang, X.H.; Yin, X.L.; Ning, H.M.; Su, R.; Lin, H.S.; Song, L.; Wang, F.; Ma, Y.N.; et al. The PU.1-Modulated MicroRNA-22 Is a Regulator of Monocyte/Macrophage Differentiation and Acute Myeloid Leukemia. PLoS Genet. 2016, 12, e1006259. [CrossRef]

168. Senyuk, V.; Zhang, Y.; Liu, Y.; Ming, M.; Premanand, K.; Zhou, L.; Chen, P.; Chen, J.; Rowley, J.D.; Nucifora, G.; et al. Critical role of miR-9 in myelopoiesis and EVI1-induced leukemogenesis. Proc. Natl. Acad. Sci. USA 2013, 110, 5594-5599. [CrossRef]

169. Garzon, R.; Liu, S.; Fabbri, M.; Liu, Z.; Heaphy, C.E.; Callegari, E.; Schwind, S.; Pang, J.; Yu, J.; Muthusamy, N.; et al. MicroRNA-29b induces global DNA hypomethylation and tumor suppressor gene reexpression in acute myeloid leukemia by targeting directly DNMT3A and 3B and indirectly DNMT1. Blood 2009, 113, 6411-6418. [CrossRef]

170. Trissal, M.C.; Wong, T.N.; Yao, J.C.; Ramaswamy, R.; Kuo, I.; Baty, J.; Sun, Y.; Jih, G.; Parikh, N.; Berrien-Elliott, M.M.; et al. MIR142 Loss-of-Function Mutations Derepress ASH1L to Increase HOXA Gene Expression and Promote Leukemogenesis. Cancer Res. 2018, 78, 3510-3521. [CrossRef]

171. Ling, K.W.; Ottersbach, K.; van Hamburg, J.P.; Oziemlak, A.; Tsai, F.Y.; Orkin, S.H.; Ploemacher, R.; Hendriks, R.W.; Dzierzak, E. GATA-2 plays two functionally distinct roles during the ontogeny of hematopoietic stem cells. J. Exp. Med. 2004, 200, 871-882. [CrossRef] [PubMed]

172. Rodrigues, N.P.; Boyd, A.S.; Fugazza, C.; May, G.E.; Guo, Y.; Tipping, A.J.; Scadden, D.T.; Vyas, P.; Enver, T. GATA-2 regulates granulocyte-macrophage progenitor cell function. Blood 2008, 112, 4862-4873. [CrossRef] [PubMed] 
173. Zhang, S.J.; Ma, L.Y.; Huang, Q.H.; Li, G.; Gu, B.W.; Gao, X.D.; Shi, J.Y.; Wang, Y.Y.; Gao, L.; Cai, X.; et al. Gain-of-function mutation of GATA-2 in acute myeloid transformation of chronic myeloid leukemia. Proc. Natl. Acad. Sci. USA 2008, 105, 2076-2081. [CrossRef] [PubMed]

174. Crispino, J.D.; Horwitz, M.S. GATA factor mutations in hematologic disease. Blood 2017, 129, $2103-2110$. [CrossRef] [PubMed]

175. Tien, F.M.; Hou, H.A.; Tsai, C.H.; Tang, J.L.; Chiu, Y.C.; Chen, C.Y.; Kuo, Y.Y.; Tseng, M.H.; Peng, Y.L.; Liu, M.C.; et al. GATA2 zinc finger 1 mutations are associated with distinct clinico-biological features and outcomes different from GATA2 zinc finger 2 mutations in adult acute myeloid leukemia. Blood Cancer J. 2018, 8, 87. [CrossRef]

176. Hou, H.A.; Lin, Y.C.; Kuo, Y.Y.; Chou, W.C.; Lin, C.C.; Liu, C.Y.; Chen, C.Y.; Lin, L.I.; Tseng, M.H.; Huang, C.F.; et al. GATA2 mutations in patients with acute myeloid leukemia-paired samples analyses show that the mutation is unstable during disease evolution. Ann. Hematol. 2015, 94, 211-221. [CrossRef]

177. Fasan, A.; Eder, C.; Haferlach, C.; Grossmann, V.; Kohlmann, A.; Dicker, F.; Kern, W.; Haferlach, T.; Schnittger, S. GATA2 mutations are frequent in intermediate-risk karyotype AML with biallelic CEBPA mutations and are associated with favorable prognosis. Leukemia 2013, 27, 482-485. [CrossRef]

178. Theis, F.; Corbacioglu, A.; Gaidzik, V.I.; Paschka, P.; Weber, D.; Bullinger, L.; Heuser, M.; Ganser, A.; Thol, F.; Schlegelberger, B.; et al. Clinical impact of GATA2 mutations in acute myeloid leukemia patients harboring CEBPA mutations: A study of the AML study group. Leukemia 2016, 30, 2248-2250. [CrossRef]

179. Hahn, C.N.; Chong, C.E.; Carmichael, C.L.; Wilkins, E.J.; Brautigan, P.J.; Li, X.C.; Babic, M.; Lin, M.; Carmagnac, A.; Lee, Y.K.; et al. Heritable GATA2 mutations associated with familial myelodysplastic syndrome and acute myeloid leukemia. Nat. Genet. 2011, 43, 1012-1017. [CrossRef]

180. Hsu, A.P.; Sampaio, E.P.; Khan, J.; Calvo, K.R.; Lemieux, J.E.; Patel, S.Y.; Frucht, D.M.; Vinh, D.C.; Auth, R.D.; Freeman, A.F.; et al. Mutations in GATA2 are associated with the autosomal dominant and sporadic monocytopenia and mycobacterial infection (MonoMAC) syndrome. Blood 2011, 118, 2653-2655. [CrossRef]

181. Ostergaard, P.; Simpson, M.A.; Connell, F.C.; Steward, C.G.; Brice, G.; Woollard, W.J.; Dafou, D.; Kilo, T.; Smithson, S.; Lunt, P.; et al. Mutations in GATA2 cause primary lymphedema associated with a predisposition to acute myeloid leukemia (Emberger syndrome). Nat. Genet. 2011, 43, 929-931. [CrossRef] [PubMed]

182. Schmidt, J.R.; Rucker-Braun, E.; Heidrich, K.; von Bonin, M.; Stolzel, F.; Thiede, C.; Middeke, J.M.; Ehninger, G.; Bornhauser, M.; Schetelig, J.; et al. Pilot Study on Mass Spectrometry-Based Analysis of the Proteome of CD34(+)CD123(+) Progenitor Cells for the Identification of Potential Targets for Immunotherapy in Acute Myeloid Leukemia. Proteomes 2018, 6, 11. [CrossRef] [PubMed]

183. Alanazi, B.; Munje, C.R.; Rastogi, N.; Williamson, A.J.K.; Taylor, S.; Hole, P.S.; Hodges, M.; Doyle, M.; Baker, S.; Gilkes, A.F.; et al. Integrated nuclear proteomics and transcriptomics identifies S100A4 as a therapeutic target in acute myeloid leukemia. Leukemia 2020, 34, 427-440. [CrossRef] [PubMed]

184. Reikvam, H.; Aasebo, E.; Brenner, A.K.; Bartaula-Brevik, S.; Gronningsaeter, I.S.; Forthun, R.B.; Hovland, R.; Bruserud, O. High Constitutive Cytokine Release by Primary Human Acute Myeloid Leukemia Cells Is Associated with a Specific Intercellular Communication Phenotype. J. Clin. Med. 2019, 8, 970. [CrossRef] [PubMed]

185. Brenner, A.K.; Aasebo, E.; Hernandez-Valladares, M.; Selheim, F.; Berven, F.; Gronningsaeter, I.S.; Bartaula-Brevik, S.; Bruserud, O. The Capacity of Long-Term in Vitro Proliferation of Acute Myeloid Leukemia Cells Supported Only by Exogenous Cytokines Is Associated with a Patient Subset with Adverse Outcome. Cancers 2019, 11, 73. [CrossRef]

(C) 2020 by the authors. Licensee MDPI, Basel, Switzerland. This article is an open access article distributed under the terms and conditions of the Creative Commons Attribution (CC BY) license (http://creativecommons.org/licenses/by/4.0/). 